\title{
European emissions of isoprene and monoterpenes from the Last Glacial Maximum to present
}

\author{
G. Schurgers ${ }^{1}$, T. Hickler ${ }^{1}$, P. A. Miller ${ }^{1}$, and A. Arneth ${ }^{1,2}$ \\ ${ }^{1}$ Lund University, Department of Physical Geography and Ecosystems Analysis, Sölvegatan 12, 22362 Lund, Sweden \\ ${ }^{2}$ University of Helsinki, Department of Physical Sciences, Helsinki, Finland
}

Received: 7 August 2009 - Published in Biogeosciences Discuss.: 3 September 2009

Revised: 25 November 2009 - Accepted: 26 November 2009 - Published: 3 December 2009

\begin{abstract}
Biogenic volatile organic compounds (BVOC), such as isoprene and monoterpenes, play an important role in atmospheric processes. BVOC species are oxidized in the atmosphere and influence levels of ozone. The less volatile amongst the BVOC and their oxidation products are important for the formation and growth of secondary biogenic aerosol. In this way, the Earth's radiation balance is affected.

Geographic distribution and temporal changes in BVOC emissions are highly uncertain. Here we assessed changes in emission patterns across Europe since the Last Glacial Maximum (LGM) with a dynamic vegetation model. This model reproduces European tree species distribution and includes a process-based algorithm for terpenoid production. In a set of simulations the model was driven with paleoclimate anomalies and reconstructed $\mathrm{CO}_{2}$ concentrations. We quantified three main driving factors for the changes in emissions of isoprene and monoterpenes since the LGM: (1) the changes in climate, with temperature changes as the most important factor affecting plant physiology and terpenoid production in all plant species, (2) a change in species distribution related to the changes in climate, causing local shifts in emission characteristics of the vegetation, and (3) a change in $\mathrm{CO}_{2}$ concentration, causing opposing effects on the availability of different substrates for terpenoid production. The effect of atmospheric $\mathrm{CO}_{2}$ concentration is particularly uncertain, but sensitivity simulations showed an increase in European BVOC emissions in all sensitivity experiments irrespective of the use of a direct inhibition of terpenoid production by $\mathrm{CO}_{2}$. The effects of climate change on physiology and terpenoid production resulted in an overall relatively uniform increase of emissions in Europe over the simulation period,
\end{abstract}

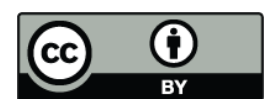

Correspondence to: G. Schurgers (guy.schurgers@nateko.lu.se) but regionally the effect of changes in species distribution and the related changes in emission capacities resulted in changes of emissions that can dominate over the physiology effects. This may have consequences for regional atmospheric chemistry simulations for the past, that have to rely on suitable geographic patterns of forest emissions.

\section{Introduction}

Since the Last Glacial Maximum, 21000 years before present, the European land surface and vegetation have changed considerably. Due to the retreat of the large ice sheets and the rise of temperatures, forests expanded from their refugia and replaced glacial tundra (Huntley, 1988). Moreover, due to the geographic expansion in response to warming, vegetated areas experienced a change in species composition. The shifting vegetation patterns did not only respond to climate change, they also fed back to climate by changing biogeophysical characteristics and biogeochemical cycles (see Claussen, 2009, for an overview). Modelling studies on glacial-interglacial changes of the biogeochemical impact have been focussing mainly on global emissions and concentrations of $\mathrm{CO}_{2}$ (see Ruddiman, 2008, for an overview), which has a long lifetime and is atmospherically well mixed. Changes in terrestrial methane emissions, affecting the concentrations of methane in the atmosphere and thereby its climatic effect, have been studied on these timescales as well (Valdes et al., 2005; Kaplan et al., 2006).

In addition to these major greenhouse gases of terrestrial origin, plants emit a large amount of reactive carbon compounds, typically grouped as non-methane hydrocarbons or biogenic volatile organic compounds (BVOC). The most important compound in this group in terms of total carbon is

Published by Copernicus Publications on behalf of the European Geosciences Union. 
isoprene $\left(\mathrm{C}_{5} \mathrm{H}_{8}\right)$, with oxidation pathways in the atmosphere that either produce or consume ozone depending on the levels of $\mathrm{NO}_{\mathrm{x}}$. In this way isoprene affects the concentrations of oxidizing compounds $\left(\mathrm{OH}, \mathrm{O}_{3}\right)$ from the atmosphere and influences lifetimes of e.g. methane and nitrous oxide. Apart from that, $\mathrm{O}_{3}$ affects plant physiology because of its toxic nature, thereby causing local feedbacks to photosynthesis (e.g. Sitch et al., 2007) and thus emissions, as well as to fluxes of BVOC by reactions within the plant and the canopy (e.g. Loreto et al., 2001). Monoterpenes, a group of compounds with the chemical formula $\mathrm{C}_{10} \mathrm{H}_{16}$, enter oxidation reactions as well. Due to their lower volatility they are considered important as precursor for secondary organic aerosol (SOA) (Hoffmann et al., 1997), although oxidation products of the more volatile isoprene have been shown to form SOA as well (Claeys et al., 2004; Kroll et al., 2005).

BVOC in the atmosphere can affect greenhouse gas lifetimes by reacting with oxidizing compounds. Kaplan et al. (2006) argued that the long-term trend in atmospheric $\mathrm{CH}_{4}$ observed in ice cores could not be explained solely by changes in wetland emissions, but requires also consideration of changes in the atmospheric sink. Such changes could result from glacial-interglacial changes in BVOC, which compete with methane for the hydroxyl radical. However, in contrast to the main greenhouse gases, the effects of isoprene and monoterpenes on atmospheric composition and aerosol formation can have a much more regional impact due to their much shorter lifetimes (up to some hours; Kesselmeier and Staudt, 1999) in the atmosphere. The importance of BVOC emissions for atmospheric chemistry, combined with the fact that emission characteristics vary considerably between plant species, make the geographic BVOC source attribution necessary but difficult as it requires both process understanding and detailed information on the distribution of plant species.

Country-wide or regional estimates of isoprene or monoterpene emissions in the literature are often based on an inventory of the main plant species (e.g. Tollsten and Muller (1996) for Switzerland), in most cases combined with modelling to account for temperature and radiation effects (e.g. Kellomaki et al. (2001) for Finland, Smiatek and Steinbrecher (2006) for Germany). Such inventories were performed for Europe as a whole as well (e.g. by Simpson et al., 1995, 1999; Karl et al., 2009; Steinbrecher et al., 2009). In these studies, the geographic species distribution is fixed, and such emission inventories are not applicable to past or future conditions because of the lack of dynamically changing, interactive effects of climate, atmospheric $\mathrm{CO}_{2}$ concentration and the terrestrial carbon and water balance on vegetation productivity, canopy structure and terpenoid emissions. Globally, BVOC emission models have been integrated into dynamic vegetation models (see Arneth et al., 2008a, for an overview), accounting for the effects of past or future changes in ecosystem physiology, and in some cases for basic changes in global plant functional type distributions as well.
In this study, we apply a vegetation model to simulate changes in the distribution of 17 of the dominant tree species and 3 generic shrub and herb types in Europe in order to obtain estimates of emissions of isoprene and monoterpenes and their changes over the last 21000 years. The simulations are performed with a consistent model framework that is based on mechanistic representations of terrestrial biogeochemical cycles and plant growth. The vegetation model is driven by changes in climate and atmospheric $\mathrm{CO}_{2}$ concentration since the Last Glacial Maximum (LGM).

Our objective is to present an estimate of the effects of climate change and migration of species on the emissions of reactive hydrocarbons over a transition from glacial to interglacial. Since the effect of $\mathrm{CO}_{2}$ concentration on terpenoid production is one of the largest uncertainties in predicting past (and future) changes, it is assessed here with a set of sensitivity experiments.

\section{Method}

\subsection{Model description}

The process-based dynamic vegetation model LPJ-GUESS (Smith et al., 2001) simulates successional vegetation development and biogeochemical processes. Tree population dynamics are simulated as in so-called forest "gap models", establishment, growth and mortality of trees, as well as disturbance events, are simulated for a number of replicate patches. Ecophysiological processes, such as photosynthesis, respiration and transpiration are derived from the dynamic global vegetation model LPJ (Sitch et al., 2003). The description of the model is provided in Smith et al. (2001), with updates of the hydrological processes in Gerten et al. (2004), and changes in establishment in Hickler et al. (2009a).

The model has been shown to reproduce forest dynamics in north-eastern US (Hickler et al., 2004), Sweden (Koca et al., 2006) and selected sites across Europe (Smith et al., 2001; Miller et al., 2008). We used the parametrization of the model for the most common tree species in Europe, as described in Miller et al. (2008) and Hickler et al. (2009a, Appendix 1), Populus tremula was added to the set of species because of its potential importance for the European isoprene budget (Arneth et al., 2008b). The parameterization of the bioclimatic limits for the different species is provided in the Appendix A, Table A1.

Emissions of isoprene and monoterpenes were simulated with a process-based model coupled to the photosynthetic electron transport rate (Niinemets et al., 1999, 2002), of which a fraction is used for terpenoid production. This fraction is parameterized for standard environmental conditions (a temperature of $30^{\circ} \mathrm{C}$ and radiation of $1000 \mu \mathrm{mol} \mathrm{PAR} \mathrm{m}^{-2} \mathrm{~s}^{-1}$ ) using species-specific standard emission capacities as obtained from measurements. Produced monoterpenes can be either emitted directly or are 
stored in storage organs. A detailed description and evaluation is given in Arneth et al. (2007b), Arneth et al. (2008b) and Schurgers et al. (2009).

Existing compilations of emission capacities from a large number of plant species (Hewitt et al., 1997; Kesselmeier and Staudt, 1999; Wiedinmyer et al., 2004) do not provide information on the geographical location of the observations. Moreover, observed emission capacities depend on the climatic circumstances in which the plant is growing (Hewitt and Street, 1992) or even on the genetic characteristics of the population (Simon et al., 2005). To reduce the possibility of biases due to such effects, we consider here primarily emission capacities obtained from measurements in the European model domain, synthesising the original publications and extending the data set with greenhouse studies or studies outside Europe in cases where the amount of data was limited (Table B1). Following Schurgers et al. (2009), published monoterpene emission capacities for those plant species that store monoterpenes (i.e. conifers) with temperature-driven release (Guenther et al., 1995) were doubled to reflect the higher production capacity that is required to maintain the storage pool with a production that takes place only during daytime.

Table B1 provides the emission capacities used in this study as well as the literature sources that these are based on. Single studies often provided a range of estimates that arise from the experimental setup (e.g. different times of observation, different branches or individuals, or different methodologies to standardize the emissions). Due to the wide range of sources of uncertainty, the listed numbers and ranges provided in the table should thus be understood as an illustration rather than as a quantification of uncertainty.

\subsection{Experiment setup}

\subsubsection{Present-day estimate}

The species composition and terpenoid emissions were simulated for the European domain west of $30^{\circ} \mathrm{E}\left(35^{\circ}-75^{\circ} \mathrm{N}\right.$; $15^{\circ} \mathrm{W}-30^{\circ} \mathrm{E}$ ) with a horizontal resolution of $0.5^{\circ}$. A 20 th century estimate of terpenoid emissions was derived by driving LPJ-GUESS with data from the Climatic Research Unit of the University of East Anglia (CRU TS 2.1, hereafter referred to as CRU data) for 1901-2000 (New et al., 2000; Mitchell and Jones, 2005). The data set is based on weather station data, which are assembled onto a regular grid. As a spinup, the model was forced by repeating 100 years of detrended data from the same data set for a total of 300 years. Atmospheric $\mathrm{CO}_{2}$ concentrations from ice cores (Etheridge et al., 1996) and direct observations (Keeling et al., 1995) were prescribed. Results from this simulation are averaged for the period 1981-2000.

In the present-day simulation, land use was not explicitly represented. To compare simulated emissions with other estimates for present-day, the relative areas of pastures and crop- lands were prescribed according to Ramankutty et al. (2008). Pastures and crops were all simulated applying the same parameter settings as used for $\mathrm{C}_{3}$ grasses in LPJ-GUESS, except for their characteristics with regard to terpenoid emissions.

\subsubsection{Paleoclimate simulations}

Changes in physiology and species composition were studied by applying data from climate simulations for the current interglacial as well as for the last glacial-to-interglacial transition. Two sets of simulations were performed: a transient simulation for the current interglacial (the Holocene, 9 ka before present (BP)-present), and a set of disjunct time periods or time slices covering the glacial-to-interglacial transition (21 ka BP-present, with slices covering most of the 1000-year intervals). In both cases, a detrended set of CRU data for 1901-2000 was used repetitively as forcing. Superimposed on this 100-year data set were anomalies from paleoclimate simulations with general circulation models. The transient simulations were integrated for 9000 years, preceded by a 300 year long spinup. The time slice simulations were integrated for 100 years, again with a spinup of 300 years.

The transient simulation between $9 \mathrm{kaBP}$ and present applied climate data from simulations with the MPI/UW Earth system model (Mikolajewicz et al., 2007). The model comprises a coupled atmosphere-ocean general circulation model, and includes ocean biogeochemistry and terrestrial vegetation. Data from a transient Holocene simulation (Schurgers et al., 2006) were summarized into 100-year averages. For the simulation, linear interpolation between these 100 -year averages was applied. The continental boundaries and the ice sheet extent were assumed not to change over the course of the simulation and were set to present-day conditions (Schurgers et al., 2006).

The glacial-to-interglacial transition was simulated with 18 time slices between $21 \mathrm{ka} \mathrm{BP}$ and $1 \mathrm{ka} \mathrm{BP}$, which was extended with a pre-industrial simulation. For each of these time slices, anomalies from simulations with the Hadley Centre Unified Model (HadSM3; Pope et al., 2000) were applied and the pre-industrial simulation was driven with detrended CRU data without anomalies. The simulations were performed for time slices every 1000 years (Bristol Research Initiative for the Dynamic Global Environment, BRIDGE, http://www.bridge.bristol.ac.uk). Changes in the extent of the land surface due to changes in land ice cover and exposure of the shelf regions (Peltier, 1994) were taken into account, the CRU data were extrapolated into the shelf regions to cover these with climate data.

The climate anomalies applied for both the interglacial and the glacial-to-interglacial simulation series are shown in Fig. 1. In general, the temperatures simulated with HadSM3 increased from the LGM onwards to the early Holocene for all regions, with a larger warming at higher latitudes. From the early Holocene onwards, both the time slice simulations 

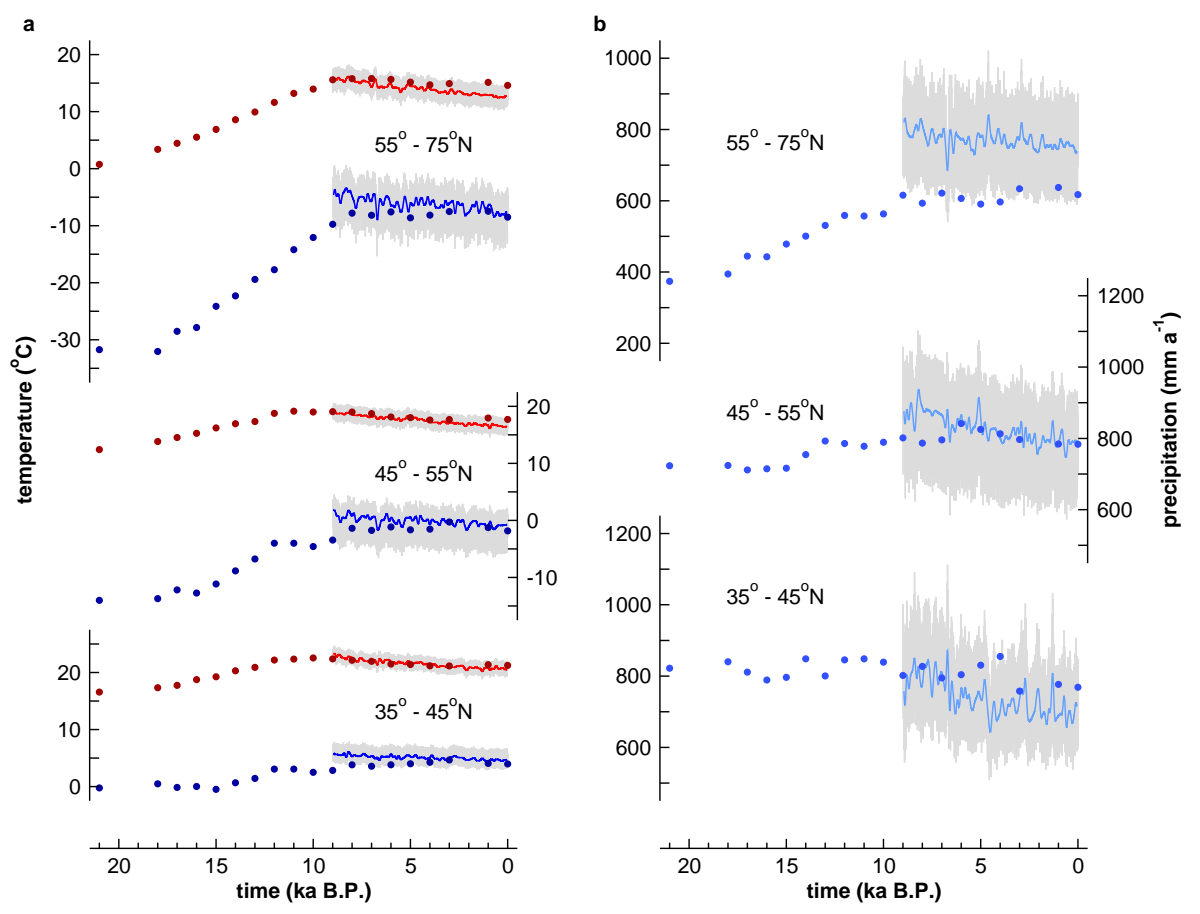

Fig. 1. Average climate data used to force the vegetation simulations for three zonal bands (land surface only): (a) summer (JJA, red) and winter (DJF, blue) temperature; (b) annual total precipitation. Solid lines are as applied for the transient interglacial simulations, with the grey band showing the year-to-year changes (originating from MPI/UW-ESM), circles are as applied for the glacial-to-interglacial time slice series (originating from HadSM3).

(HadSM3) and the transient simulation (MPI/UW Earth system model) showed either a decreasing or a stabilizing trend in temperature, again with a more pronounced effect for the higher latitudes (Fig. 1). The initial increase and subsequent decrease were simulated for both summer and winter, with slightly larger changes in winter. Precipitation trends were comparable, with an initial increase during deglaciation followed by a slight decrease during the Holocene, particularly in the transient simulation, although the trend is less pronounced and deviations from this pattern can be found in the time slices for northern Europe (showing a continuous increase in precipitation) and southern Europe (showing a more stable precipitation regime for the deglaciation period).

$\mathrm{CO}_{2}$ concentrations for the simulations were prescribed: for the time slices, the concentrations as applied in the paleoclimate simulations with HadSM3 were used, with the $0 \mathrm{kaBP}$ time slice representing a pre-industrial case $(280 \mathrm{ppm})$. For the transient simulation we used a reconstruction of $\mathrm{CO}_{2}$ concentrations based on ice core data (Indermühle et al., 1999; Friedli et al., 1986; Etheridge et al., 1996), extended with observations from Mauna Loa (Hawaii) and Jubany (Antarctica) for the post-1950 period (Keeling et al., 1995). Orbital parameters were varied for all simulations according to Berger (1978). Land use has been omitted throughout the paleoclimate simulations, the simulated vegetation represents a potential natural case.
Changes in atmospheric $\mathrm{CO}_{2}$ concentration can have a number of different, partially opposing, effects on terpenoid emissions: lower $\mathrm{CO}_{2}$ concentrations in the past resulted in lower photosynthesis rates and thereby a lower leaf area, which reduces emissions compared to present. Reduced photosynthesis rates lower the availability of glyceraldehyde-3phosphate (GA-3-P) as well, which is a substrate for terpenoid production. However, greenhouse studies have shown a partial decoupling between photosynthesis and isoprene emission at a range of $\mathrm{CO}_{2}$ concentrations. In plants grown at below-ambient $\mathrm{CO}_{2}$ concentrations isoprene production may be substantially enhanced (Possell et al., 2005). Although this effect has not yet been fully understood, one hypothesis relates it to the availability of phosphoenolpyruvate (PEP) (Rosenstiel et al., 2003), a second key substrate for terpenoid production, that is used for many other cellular processes as well. This inhibition was incorporated in the isoprene model by relating production to the inverse of atmospheric $\mathrm{CO}_{2}$ concentration (Arneth et al., 2007b). The model was parametrized to have no effect on production at an atmospheric $\mathrm{CO}_{2}$ concentration of $370 \mathrm{ppm}$. This inhibition was adopted here as well for monoterpene production, because the cellular pathways for isoprene and monoterpene production are near-identical. Cellular processes that lead to the $\mathrm{CO}_{2}$-isoprene inhibition should therefore in principle also apply for monoterpene production. However, the number of studies on the effect of $\mathrm{CO}_{2}$ concentration on monoterpene 
production is limited, and the emerging picture is not uniform (e.g. Constable et al., 1999; Staudt et al., 2001; Snow et al., 2003; Baraldi et al., 2004; Llorens et al., 2009).

To assess the uncertainty related to the response to $\mathrm{CO}_{2}$ concentration separately, three sets of simulations were performed: (1) a simulation in which the inhibition according to Arneth et al. (2007b) is taken into account, (2) one in which this inhibition is ignored, and (3) one in which both the $\mathrm{CO}_{2}$ fertilization effect on photosynthesis and the inhibition are ignored. In the latter case, the simulations were performed prescribing an atmospheric $\mathrm{CO}_{2}$ concentration of $280 \mathrm{ppm}$ to demonstrate the effect of climate change only.

\section{Results}

\subsection{Present-day species distribution}

The present-day potential natural vegetation distribution simulated by LPJ-GUESS is shown in the Appendix (Fig. A1). For an estimate of "real" present-day vegetation patterns and emissions, this natural vegetation pattern was corrected with land use obtained from Ramankutty et al. (2008). The distribution of natural and man-made vegetation types is displayed in Fig. A2.

For a present-day climate, the simulated potential natural vegetation in northern Europe is dominated by conifers Picea abies and Pinus sylvestris as well as by birch (Betula pubescens). In northern mountain areas evergreen shrubs are prominent. For Central Europe, a broad mixture of tree species is present, dominated by Fagus sylvatica (Germany) and Quercus robur. In the southern part of Europe, around the Mediterranean, drought and warm temperature tolerant species like Quercus ilex and Pinus halepensis become competitive, with understorey vegetation formed by raingreen shrubs and $\mathrm{C}_{3}$ herbs.

The tree species distribution on European scale simulated with LPJ-GUESS was evaluated by Hickler et al. (2009b), who found good agreement with observed species composition and vegetation structure at ten pristine forests across Europe and with an expert reconstruction of potential natural vegetation, classified into vegetation types (Bohn and Neuhäusl, 2003). A comparison of the simulated distribution of single tree species with the observed distribution given in the Atlas Flora Europeae (http://www.fmnh.helsinki. fi/english/botany/afe/index.htm) showed also reasonable to good agreement on actual species level. Species were found in the correct region, although in some cases the boundaries of the domain were not well-represented. Several tree species were simulated to occur throughout large parts of Spain, further south than their actual range (e.g. Quercus robur, Fagus sylvatica, Quercus ilex, Pinus halepenesis), but LAI for these species was in general low. Some mediterranean species extended too far northward along the Atlantic coast (Quercus coccifera, Juniperus oxycedrus).
The present-day European land cover is dominated by cropland and pastures (e.g. Ramankutty et al., 2008, Fig. A2). Only remote regions (e.g. northern Scandinavia) are still largely untouched by anthropogenic land cover change. In total, about $32 \%$ of the calculated total European leaf area was formed by crops, and another $16 \%$ by pastures. The largest contributions to total leaf area from natural vegetation come from conifers as Picea abies (9\%) and Pinus sylvestris (4\%), as well as from a few dominant broadleaved tree species (Quercus robur, 8\%, Fagus sylvatica, 8\%, Quercus ilex, $3 \%$ ) and herbs (3\%). Forest management, which is not implemented here, will likely change these numbers to some degree, as management decisions tend towards the use of conifers (for Europe mainly Pinus sylvestris and Picea abies) rather than broadleaf species in many places.

\subsection{Present-day budget of isoprene and monoterpene emissions}

The annual total isoprene and monoterpene fluxes for the simulated European domain were of similar magnitude. Isoprene emissions summed up to $1.2 \mathrm{Tg} \mathrm{Ca}^{-1}$, monoterpene emissions to $2.0 \mathrm{TgCa}^{-1}$. Both the biogenic isoprene and the monoterpene emissions originated primarily from the natural vegetation, since most crops and grasslands tend to be neither large isoprene nor large monoterpene emitters (Kesselmeier and Staudt, 1999). The reduction in forest cover due to anthropogenic land use reduced the European emissions of both isoprene and monoterpenes by almost $50 \%$ compared to emissions from potential natural vegetation. Summer emissions dominate the annual budget, with $72 \%$ of the isoprene emissions and $53 \%$ of the monoterpene emissions occurring in the three summer months (June, July and August).

Emissions of isoprene were largest in Central Europe (Fig. 2a, c) where several broadleaved tree species that are known to be relatively high isoprene emitters (e.g. Quercus robur) are dominant. Since these tend to be deciduous trees, wintertime emissions for isoprene were low (Fig. 2a). Monoterpene emissions dominated the northern and Mediterranean part of Europe (Fig. 2b, d), but western Europe has high emissions as well. In the northern forests, monoterpenes were primarily emitted from coniferous trees (Pinus sylvestris, Picea abies), whereas the mediterranean Quercus ilex dominates the emission pattern in the south, together with relatively large emissions from Quercus coccifera and mediterranean shrubs. In Germany and France relatively high monoterpene emissions were simulated originating from Fagus sylvatica. Overall, the isoprene-emitting oaks were the most important species for the total isoprene budget: Quercus robur is responsible for more than $60 \%$ of the European isoprene emissions, followed in importance by Populus tremula, Quercus pubescens, Mediterranean shrubs and Picea abies (all between 6 and $8 \%$ of the total budget). For monoterpenes, the main emitters are Fagus sylvatica 
(34\% of the total budget), Picea abies (24\%) and Quercus ilex (13\%).

These total European emissions are comparable to previously published estimates for Europe. Because the different studies hardly ever use the same definition of Europe when it comes to the actual area studied, we express emissions on an area basis for cross-study comparison. Average emissions for $1981-2000$ are $0.20 \mathrm{~g} \mathrm{C} \mathrm{m}^{-2} \mathrm{a}^{-1}$ for isoprene and $0.33 \mathrm{~g} \mathrm{C} \mathrm{m}^{-2} \mathrm{a}^{-1}$ for monoterpenes from our simulations. Using a slightly older version of the vegetation model, Arneth et al. (2008b) simulated average isoprene emissions of $0.34 \mathrm{~g} \mathrm{C} \mathrm{m}^{-2} \mathrm{a}^{-1}$ for the 15 pre-enlargement EU countries, Switzerland and Norway, averaged over the same time period. Simpson et al. (1995) calculated values between 0.19 and $0.45 \mathrm{~g} \mathrm{C} \mathrm{m}^{-2} \mathrm{a}^{-1}$ for a much larger area (including part of the former Soviet Union). The range of estimates from Simpson et al. (1995) originates from the application of different algorithms (with dependencies on temperature and/or light) that were published at that time.

Karl et al. (2009) used the commonly applied algorithms by Guenther et al. (1995) combined with a detailed distribution of plant species and functional types to calculate estimates, resulting in $0.19 \mathrm{~g} \mathrm{C} \mathrm{m}^{-2} \mathrm{a}^{-1}$ for isoprene. Finally, Steinbrecher et al. (2009) recently provided detailed estimates for July 2003, with average isoprene emissions of $0.23 \mathrm{~g} \mathrm{C} \mathrm{m}^{-2}$ month $^{-1}$ and monoterpene emissions of $0.16 \mathrm{~g} \mathrm{C} \mathrm{m}^{-2}$ month $^{-1}$. Our averages for July are considerably lower: $0.057 \mathrm{~g} \mathrm{C} \mathrm{m}^{-2} \mathrm{month}^{-1}$ for isoprene and $0.066 \mathrm{~g} \mathrm{C} \mathrm{m}^{-2}$ month $^{-1}$ for monoterpenes (averaged for 1981-2000). This difference is likely caused by the difference in the algorithm, by a smaller reduction due to land use in the study by Steinbrecher et al. (2009), as well as by the focus on July 2003, which is particularly warm as compared to our 1981-2000 average.

\subsection{Vegetation changes since the Last Glacial Maximum}

Early in the simulation period, during the glacial, forest cover was scarce in most parts of Europe. Though western Europe was covered by coniferous forests, forest LAI does not exceed 2.5 in most regions. Herbaceous vegetation is important in southern Europe, and LAI is generally low (Fig. 3). Eastern and southern Europe were primarily covered by herbaceous vegetation. Since the Last Glacial Maximum, LAI increased substantially in central and northern Europe as the ice cover retreated and the climate warmed. With the disappearance of the ice sheet LAI reached values well above 2 for most of the European area (Fig. 3).

In addition to the general increase in LAI, the simulations indicated substantial zonal shifts of the main species, as summarized in Fig. 4a. With the warming climate, Pinus sylvestris shifts north- and eastward, broadleaf trees become competitive across Central Europe. In the Central European band $\left(45^{\circ}-55^{\circ}\right)$, temperate broadleaf trees such as Quercus robur and Fagus sylvatica show a rapid increase from
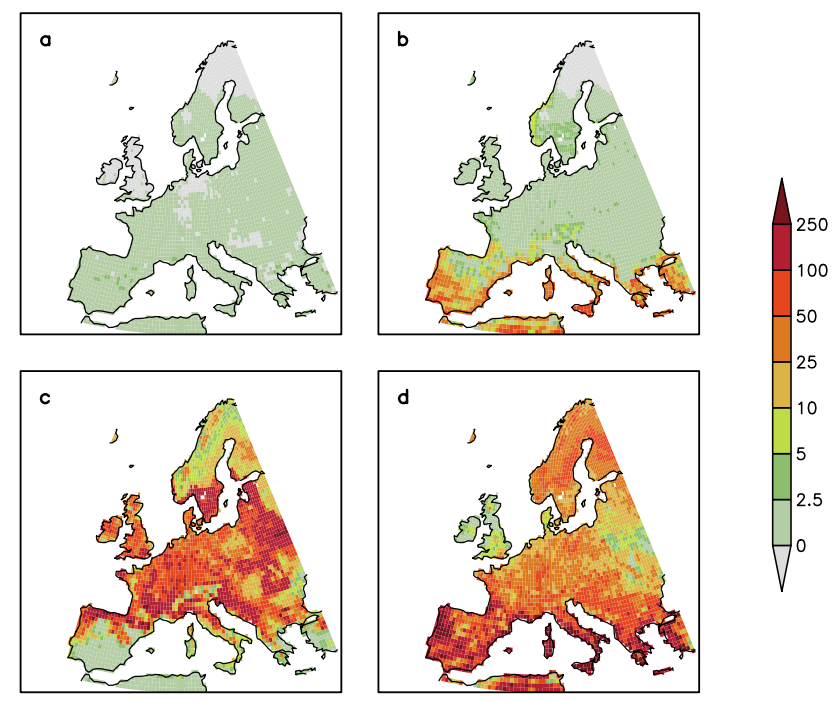

Fig. 2. Simulated monthly emissions $\left(\mathrm{mg} \mathrm{C} \mathrm{m}^{-2} \mathrm{month}^{-1}\right)$ of (a, c) isoprene and (b, d) monoterpenes averaged for (a,b) January and (c, d) July 1981-2000. Emissions are corrected for land use applying land use data from Ramankutty et al. (2008).

$15 \mathrm{kaBP}$ onwards (Fig. 4a2). Over the time slices, Quercus ilex extended gradually from the southern mediterranean coasts to the north, covering large parts of Spain, Italy and Greece, and some parts of France. For the shorter transient Holocene simulations, results were comparable to those from the time slices (not shown).

\subsection{Changes in isoprene and monoterpene emissions since the Last Glacial Maximum}

Lower temperatures at the Last Glacial Maximum were an important driver for lower canopy photosynthesis and terpenoid production compared to the interglacial period (Fig. 5b, c). About half of the overall increase in gross primary production (GPP) since the Last Glacial Maximum can be attributed to changes in climate, the other half is caused by the increase in atmospheric $\mathrm{CO}_{2}$ concentration (Fig. 5a). Additionally, notable changes in the regional patterns of GPP resulted also from changes in the extent of the land surface: The increase of GPP in Northern Europe due to the retreat of ice sheets and the establishment of vegetation was largely compensated by a loss of land and thus vegetation in the shallow North Sea, between France and England, and along the Mediterranean coast (not shown). GPP decreased in the Mediterranean once warmer climate and decreased precipitation caused soil water deficits to occur regularly (Fig. 1).

The relative increase in isoprene and monoterpene emissions was larger than the increase in GPP during the glacialto-interglacial transition, despite the counteracting effect of $\mathrm{CO}_{2}$ inhibition (Fig. 5). This reflects the higher temperature optimum as well as the higher temperature sensitivity of terpenoid production compared to photosynthesis. The 
o. 21 ka B.P.

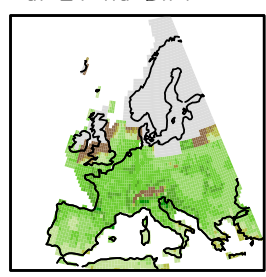

b. 16 ka B.P.

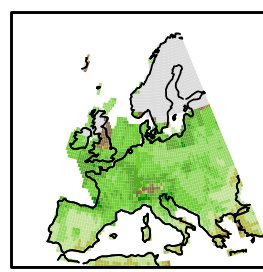

c. 11 ko B.P.

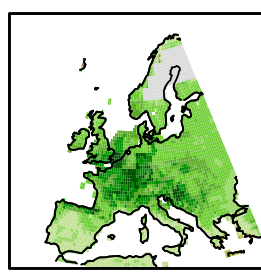

d. 6 ka B.P.

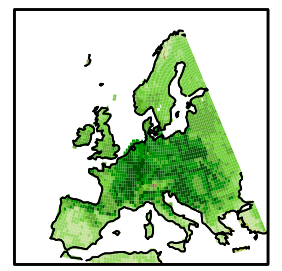

๑. 0 ka B.P.

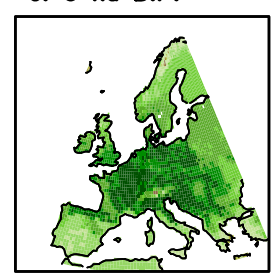

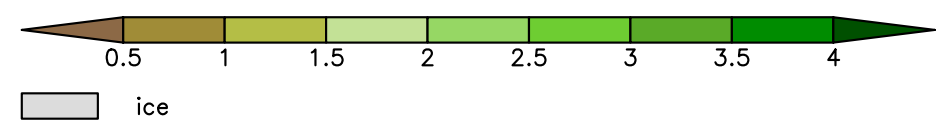

Fig. 3. Simulated LAI for selected time slices (a) $21 \mathrm{ka} \mathrm{BP,} \mathrm{(b)} 16 \mathrm{ka} \mathrm{BP}$, (c) $11 \mathrm{ka} \mathrm{BP}$, (d) $6 \mathrm{ka} \mathrm{BP,} \mathrm{(e)} 0 \mathrm{ka} \mathrm{BP}$.
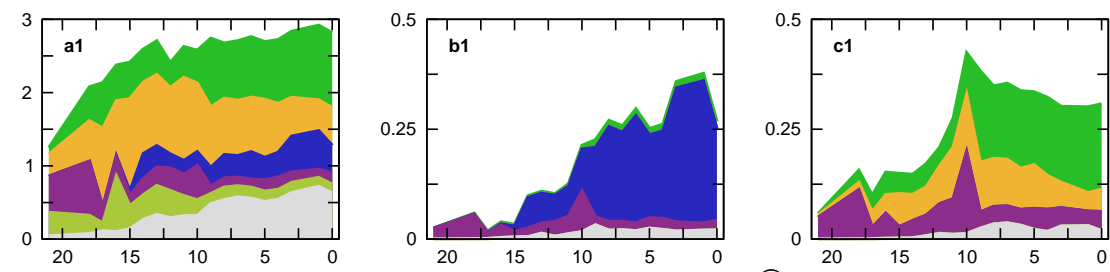

$55^{\circ}-75^{\circ} \mathrm{N}$

Picea abies

- Quercus robur

Boreal evergreen shrub

$\mathrm{C}_{3}$ herbs
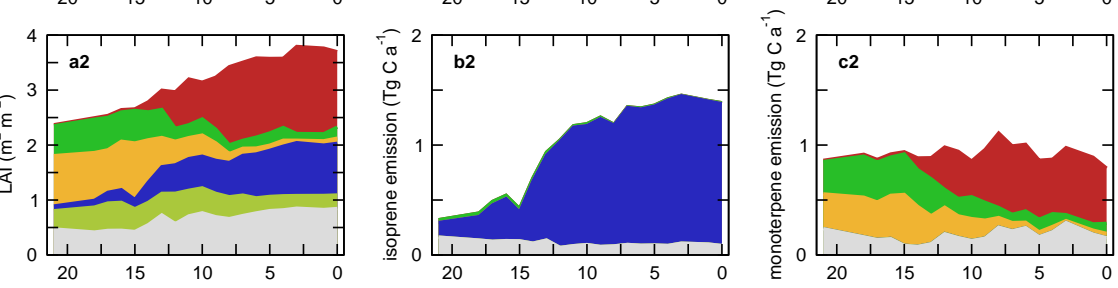

Other species
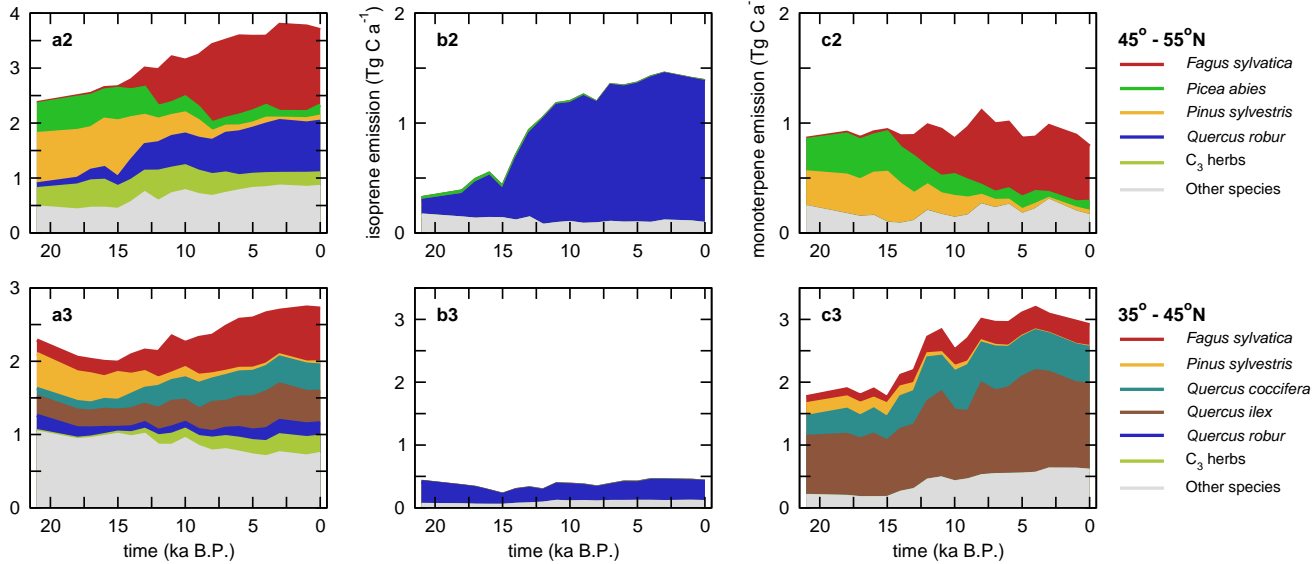

Fig. 4. Simulated changes in (a) LAI, (b) isoprene and (c) monoterpene emissions for the glacial-to-interglacial time slices, separated for the most abundant species in the three zonal bands: (1) $55^{\circ}-75^{\circ} \mathrm{N}$; (2) $45^{\circ}-55^{\circ} \mathrm{N}$; (3) $35^{\circ}-45^{\circ} \mathrm{N}$. Please note that the LAI for each time slice is given relative to the land area of that slice, changes in the extent of the continents due to glacier cover and sea level rise cause substantial changes in the absolute amount of leaf area.

strongest relative increase in isoprene emissions was located in Northern and Central Europe (Fig. 4b), where emissions overall were relatively small for the LGM. From $15 \mathrm{ka}$ BP onwards, isoprene emissions in northern and central Europe and monoterpene emissions in southern Europe increased gradually (Fig. 4b, c), related to the expansion of oak trees (the isoprene-emitting Quercus robur in northern and central Europe and the monoterpene-emitting Quercus ilex and Quercus coccifera in southern Europe). At the same time, enhanced temperatures and the retreat of the ice sheet around the Baltic Sea caused the monoterpene emissions from coniferous trees (Picea abies and Pinus sylvestris) to increase as well (Fig. 4c1). Between 15 and $10 \mathrm{kaBP}$, the relative abun- dance of coniferous trees decreased considerably in central and southern Europe. However, due to the simultaneous expansion of monoterpene-emitting broadleaf trees, such as $\mathrm{Fa}$ gus sylvatica in central Europe and Quercus ilex and Quercus coccifera in southern Europe, monoterpene emissions remained constant in central Europe and increased in southern Europe.

After $11 \mathrm{ka} \mathrm{BP}$, total emissions in Europe had largely stabilized (Fig. 5b, c) both in the time slices and in the transient simulation, although pronounced shifts still occurred in the regional patterns (not shown). Isoprene emissions increased in France as well as in large parts of eastern Europe, related to emissions from Quercus robur. Monoterpene 

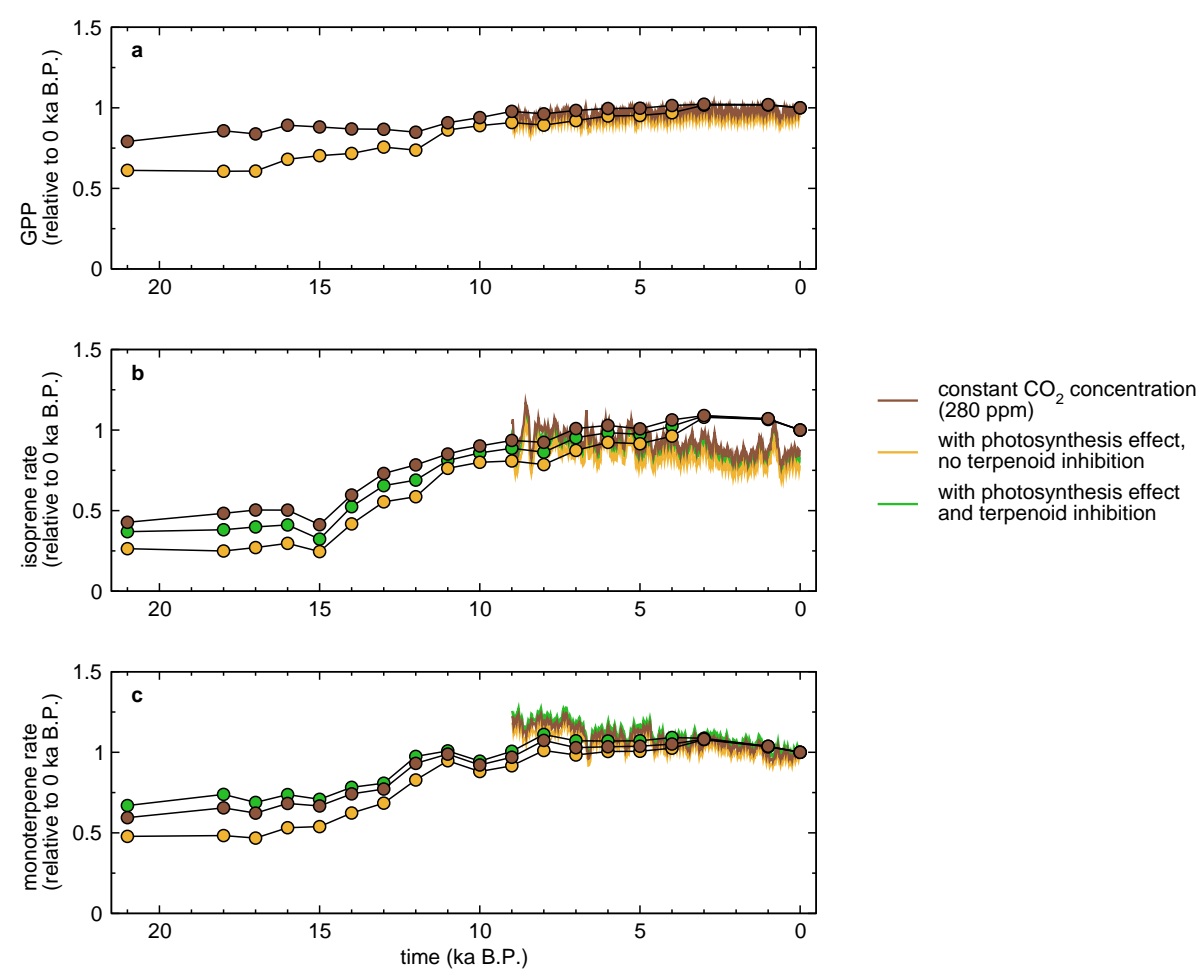

Fig. 5. Sensitivity of annual total European (a) GPP, (b) isoprene and (c) monoterpene emissions to the simulated influence of atmospheric $\mathrm{CO}_{2}$ concentration. Shown are sets of simulations with a constant $\mathrm{CO}_{2}$ concentration of $280 \mathrm{ppm}$, with a varying $\mathrm{CO}_{2}$ concentration affecting photosynthesis, but without a direct inhibition of VOC production, and with a varying $\mathrm{CO}_{2}$ concentration affecting photosynthesis and inhibiting VOC production. All results are shown relative to the value for $0 \mathrm{ka} \mathrm{BP}$, see text for absolute values.

emissions decreased in these areas, mainly related to retreating conifers. An increase in monoterpene emissions was simulated for Germany (related to expansion of Fagus sylvatica) and some regions around the mediterranean (related to expansion of Quercus ilex).

\subsection{Sensitivity to changes in $\mathrm{CO}_{2}$ concentration}

The three sets of sensitivity experiments to the effect of $\mathrm{CO}_{2}$ changes on terpenoid emissions result in different emissions for the $0 \mathrm{kaBP}$ time slice. Because all $0 \mathrm{kaBP}$ simulations were forced with an atmospheric $\mathrm{CO}_{2}$ concentration of $280 \mathrm{ppm}$, the only difference between the simulations is whether or not the direct $\mathrm{CO}_{2}$ inhibition effect is taken into account (in the model, the $\mathrm{CO}_{2}$ effect is expressed as a multiplier that becomes unity for present-day, defined as $370 \mathrm{ppm})$. Total European isoprene emissions are $1.6 \mathrm{Tg} \mathrm{Ca}^{-1}$ for the $0 \mathrm{kaBP}$ simulations without $\mathrm{CO}_{2}$ inhibition, and $2.1 \mathrm{Tg} \mathrm{Ca}^{-1}$ for the simulation with $\mathrm{CO}_{2}$ inhibition. For monoterpenes these totals are $3.0 \mathrm{Tg} \mathrm{Ca}^{-1}$ and 4.0 $\mathrm{Tg} \mathrm{Ca}^{-1}$, respectively. The below-ambient (e.g. preindustrial) $\mathrm{CO}_{2}$ concentrations enhance the emissions of terpenoids.

The different ways of accounting for $\mathrm{CO}_{2}$ effects affect not only the absolute value for $0 \mathrm{kaBP}$, but it influences the relative increase in emissions between the LGM and $0 \mathrm{kaBP}$ as well (Fig. 5b, c). Compared to the simulation with $\mathrm{CO}_{2}$ effects on both photosynthesis and terpenoid production, the set of experiments without the application of the direct inhibition of terpenoid production by $\mathrm{CO}_{2}$ has an enhanced increase for both isoprene and monoterpenes, because it lacks the stimulating effect of (low) glacial $\mathrm{CO}_{2}$ concentrations. For the simulations with a constant $\mathrm{CO}_{2}$ concentration there are two opposing effects: the enhanced photosynthesis (Fig. 5a) provides more substrates for terpenoid production, but the stimulating effect of glacial $\mathrm{CO}_{2}$ concentrations is lacking. For isoprene the former effect dominates, whereas for monoterpenes it is the latter effect that has the largest influence. This difference between the two terpenoids is mainly determined by changes in the species distribution: the pre-industrial $\mathrm{CO}_{2}$ level results in more trees as compared to glacial $\mathrm{CO}_{2}$ concentrations, which is particularly important in Central Europe, where isoprene-emitting Quercus robur replaces herbaceous vegetation.

\section{Discussion}

Although simulated forest cover was considerably reduced at the LGM compared to present-day, some regions were possibly still overestimated. Huntley (1988) described a "tundra-like" vegetation north of the Alps for the glacial. 
The simulated changes in species distribution since the LGM show in many regions reasonable agreement with patterns reconstructed based on pollen records (Huntley, 1988). A rapid spread of forests, particularly the broadleaved species, has been reconstructed from pollen data for the post-glacial period (10-7 ka BP, Huntley, 1988). The expansion of $\mathrm{Fa}$ gus sylvatica in mid latitudes, which was simulated to start around $12 \mathrm{kaBP}$ (Fig. 4a2), occurred too fast compared to pollen-based reconstructions (Huntley, 1988; Lang, 1994). The expansion of Picea abies, which was simulated to start extending its presence northward along the Norwegian coast and in southern Finland from $9 \mathrm{kaBP}$ onwards, is too early compared to reconstructions as well: Giesecke and Bennett (2004) predict the largest expansion some 2000-5000 years later. The processes underlying these late spreads of Picea abies and Fagus sylvatica are not well understood (Giesecke and Bennett, 2004; Giesecke et al., 2007). For the Iberian peninsula, the expansion of some tree species, in particular Quercus ilex and Q. coccifera, occurred too early as compared to reconstructions based on pollen observations (Fletcher and Sánchez-Goñi, 2008).

Despite the fact that certain drivers that could play a role in the determination of expansion rates or species composition, such as seed dispersal or human activity, are missing in our modelling approach, the general trends in European vegetation changes were captured by the model. With a gradual but steady change in the climate as has occurred since the Last Glacial Maximum, many of the observed vegetation changes can be attributed to this climate change. However, the factors mentioned above that are not accounted for in the simulations could affect e.g. the timing of these changes on centennial to millennial timescales. Although the two data sets of paleoclimate simulations with GCMs that were used to derive climate anomalies have relatively similar trends in temperature and precipitation in Europe, this input data is nevertheless a source of uncertainty as well.

In contrast to global total BVOC emissions that are by far dominated by isoprene in terms of carbon mass (e.g. Levis et al., 2003; Lathière et al., 2006; Arneth et al., 2008a), in Europe the amounts of carbon emitted as isoprene and as monoterpenes are of similar magnitude. This difference reflects - at least partly - a strong contribution of coniferous forest emissions to the total European budget, with conifers being much more characterised by monoterpene than by isoprene emissions, which was also found in previous studies on country-wide or European total BVOC estimates, e.g. Smiatek and Steinbrecher (2006) for Germany, or Kellomaki et al. (2001) for Finland. In addition to these differences in tree species composition, it becomes apparent that the emission capacities for isoprene that were found in the literature survey for European species (Table B1) are generally lower than the isoprene emission capacities assigned to PFTs in global models (8- $45 \mu \mathrm{g} \mathrm{g}^{-1} \mathrm{DW} \mathrm{h}^{-1}$ for temperate or boreal broadleaf deciduous or evergreen trees, Levis et al., 2003; Naik et al., 2004; Lathière et al., 2006). For monoterpenes the opposite can be observed: monoterpene emission capacities found for many European trees exceed the emission capacities used in global models $\left(0.8-2.4 \mu \mathrm{g} \mathrm{g}^{-1} \mathrm{DW} \mathrm{h}^{-1}\right.$ for temperate or boreal broadleaf deciduous or evergreen trees, Levis et al., 2003; Naik et al., 2004; Lathière et al., 2006) considerably.

The effects of $\mathrm{CO}_{2}$ concentration on terpenoid emissions are a large source of uncertainty for simulating past emissions, and there is no obvious explanation for a physiological advantage of emitting more isoprene (or terpenoids in general) during glacial periods (Possell et al., 2005). Recently, Wilkinson et al. (2009) argued that the short-term and longterm response of isoprene emissions to changes in the $\mathrm{CO}_{2}$ growth environment are similar, varying both the growth environment $\mathrm{CO}_{2}$ concentration and the cuvette $\mathrm{CO}_{2}$ concentration in their experiments. For monoterpene emissions, the number of studies on $\mathrm{CO}_{2}$ effects is smaller and shows a less uniform picture (Constable et al., 1999; Staudt et al., 2001; Snow et al., 2003; Baraldi et al., 2004; Llorens et al., 2009), and there is a strong need for measurements at belowambient $\mathrm{CO}_{2}$ concentrations in order to judge the similarity with the isoprene- $\mathrm{CO}_{2}$ relation. On a global scale, the stimulating effect of low atmospheric $\mathrm{CO}_{2}$ concentrations for the LGM might largely offset the decrease in emissions by lower temperatures (Arneth et al., 2007a). By contrast, Heald et al. (2009) found only minor effects of changes in $\mathrm{CO}_{2}$ concentration as compared to the effect of temperature changes, using the relationship derived by Wilkinson et al. (2009). In our European simulations the climate effect is clearly dominating over a possible stimulating effect from low $\mathrm{CO}_{2}$ concentrations, which is caused by the large temperature change that took place in Europe as compared to the global average, and by the fact that the mid- and high-latitudes were in the climatic range where the existence of vegetation (and forest in particular) is critically affected by climate. The latter effect was even enhanced by the presence of a large ice cover during the LGM.

As in all previous studies, the estimated isoprene and monoterpene budgets rely heavily on observations of leafscale emission capacities. The amount and applicability of leaf emission data differs considerably between species: whereas certain species appear well-studied, with measurements done at several locations within Europe (e.g. for Picea abies or Pinus sylvestris, see Table B1 and Fig. A1), we have to rely on one or two observations for other species. Likewise, certain regions are well-covered by observations (e.g. Scandinavia or the Mediterranean), whereas for other regions few published data are available. With few exceptions, the emission capacities in Table B1 were determined during the summer season only, when leaves are fully developed. A seasonality of terpenoid activity, as observed in field studies, has been implemented in the model for isoprene emissions from deciduous trees (an adjusted version of the seasonality proposed by Arneth et al., 2007b). 
Comparison of simulation results with pollen reconstructions (Miller et al., 2008) allows the evaluation of simulated vegetation distribution over long timescales. Together with the benchmarking of LPJ and LPJ-GUESS against presentday carbon and water cycles on ecosystem and global scale (Sitch et al., 2003; Gerten et al., 2004; Morales et al., 2005), this gives confidence in the general performance of the vegetation model. In contrast, the absence of reliable proxy data for isoprene or monoterpene concentrations in the atmosphere presents a severe problem for the evaluation of regional or even global changes in their emissions. Some oxidated compounds, such as formate and acetate, were observed from ice cores (Legrand and De Angelis, 1995; Fuhrer and Legrand, 1997; Savarino and Legrand, 1998), but these compounds are thought to be primarily emitted directly from decomposing material rather than resulting from atmospheric oxidation of terpenoids. However, Legrand et al. (2003) attribute part of the formate and acetate from an ice core from the Alps to oxidation of isoprene and $\alpha$-pinene. A general problem with atmospheric oxidation products related to BVOC in ice cores lies in the many unknown factors in terms of emissions, reaction mechanisms and atmospheric transport, as well as in their high reactivity. As long as the changes in their concentrations cannot be reliably assigned to changes in source or sink strengths, they will not be suitable as proxy data for this purpose.

\section{Conclusions}

Since the Last Glacial Maximum, total emissions of isoprene and monoterpenes over Europe have been simulated to rise. This is partly caused by higher temperatures, affecting plant physiology directly, and partly by a rise in vegetation abundance in Europe. Changes in atmospheric $\mathrm{CO}_{2}$ concentration can have opposing effects, but the climate effect dominates over a possible $\mathrm{CO}_{2}$ inhibition of terpenoid production for most regions and for Europe as a whole.
The summed European budgets are driven by these two direct factors, that have a reasonably uniform effect over most of Europe. The regional emission patterns, however, depend very much on changes in species composition, which gives a much less uniform indirect effect. Because of the asymmetric distribution of emission capacities over plant species associated with certain vegetation or climate zones, the trends in regional BVOC emissions are highly variable, and estimated trends are hard to generalise for the whole European domain. Modelling studies that resolve emissions based on species are necessary to make quantitative or even qualitative predictions and descriptions of the changes.

On a European scale, the rise in emissions of isoprene and monoterpenes since the Last Glacial Maximum will have had a reducing impact on oxidizing compounds and an increasing impact on lifetimes of reduced compounds such as the greenhouse gases methane and nitrous oxide. However, for assessing the net changes of these properties, as well as a more quantitative evaluation of the atmospheric chemistry, and the regional impact in particular, simulations with atmospheric chemistry models are required. The simulation of BVOC emissions presented here could function as an input to such model simulations. 
Appendix A
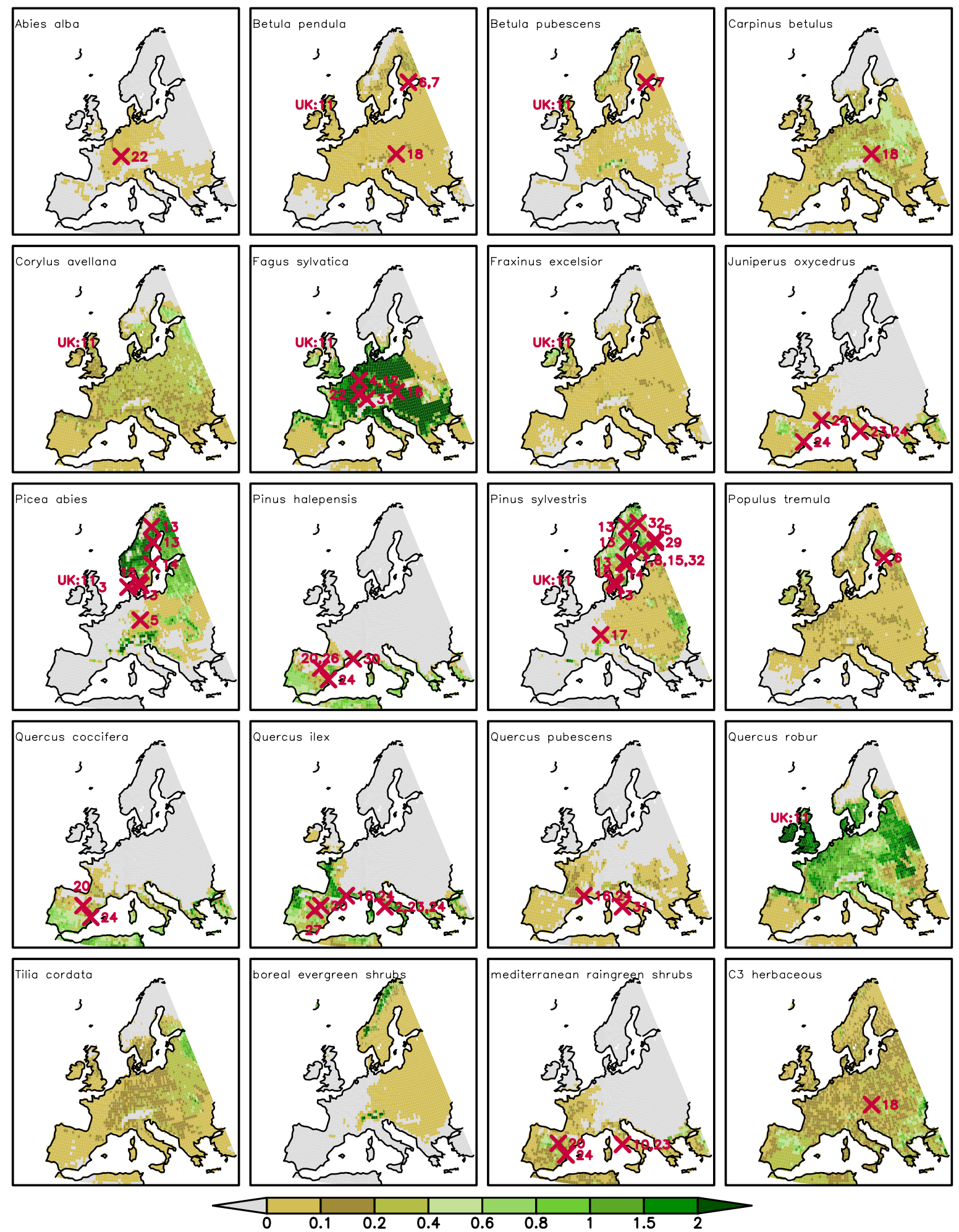

Fig. A1. Simulated leaf area index for a potential natural vegetation (averaged for 1981-2000) for the 17 tree species, two generic shrub types and herbs. Crosses indicate the locations of observations for emission capacities from Table B1, numbers refer to references therein. 


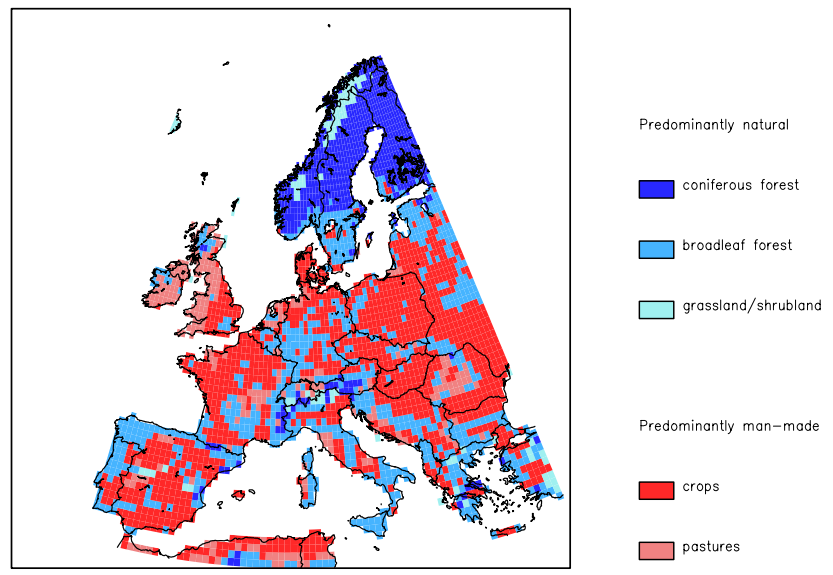

Fig. A2. Land cover types as constructed for present-day from the simulation of natural vegetation and the man-made land cover by Ramankutty et al. (2008): predominantly natural cover types (in blue colours) and predominantly man-made cover types (in red colours). The classification was based on LAI.

\section{Appendix A}

\section{Vegetation model details}

The bioclimatic limits for the different species as used in the model are reported in Table A1.

The resulting present-potential distribution of species is given in Fig. A1, together with the locations for which observations of emission capacities are available (see Table B1 for an overview of the observations). The classification of the land surface for the present-day estimates is provided in Fig. A2.
Table A1. Bioclimatic limits applied for the simulation of species: minimum coldest month temperature $T_{c \text {, min }}$; maximum coldest month temperature $T_{c \text {, max }}$; minimum growing degree-day sum $\mathrm{GDD}_{5}$; minimum soil water content for establishment $w_{\min }$.

\begin{tabular}{lrrrr}
\hline & $\begin{array}{r}T_{c, \min } \\
\left({ }^{\circ} \mathrm{C}\right)\end{array}$ & $\begin{array}{r}T_{c, \max } \\
\left({ }^{\circ} \mathrm{C}\right)\end{array}$ & $\begin{array}{r}\mathrm{GDD}_{5} \\
\left({ }^{\circ} \mathrm{C} \mathrm{d}\right)\end{array}$ & $\begin{array}{r}w_{\min } \\
(-)\end{array}$ \\
\hline Abies alba & -2 & 2 & 1600 & 0.40 \\
Betula pendula & -30 & 7 & 700 & 0.42 \\
Betula pubescens & & 3 & 350 & 0.50 \\
Carpinus betulus & -8 & & 1200 & 0.33 \\
Corylus avellana & -11 & & 800 & 0.30 \\
Fagus sylvatica & -5 & & 1500 & 0.30 \\
Fraxinus excelsior & -15 & & 1100 & 0.40 \\
Juniperus oxycedrus & 1 & & 2200 & 0.01 \\
Picea abies & -30 & -1.5 & 600 & 0.43 \\
Pinus halepensis & 4 & & 3000 & 0.05 \\
Pinus sylvestris & -30 & -1 & 500 & 0.25 \\
Populus tremula & -30 & 6 & 500 & 0.40 \\
Quercus coccifera & 2 & & 2700 & 0.10 \\
Quercus ilex & 3 & & 1800 & 0.15 \\
Quercus pubescens & -6 & & 2300 & 0.35 \\
Quercus robur & -9 & & 900 & 0.32 \\
Tilia cordata & -11 & & 1100 & 0.33 \\
Boreal evergreen shrubs & & -1 & 200 & 0.25 \\
Mediterranean raingreen & 1 & & 2200 & 0.01 \\
low shrubs & & & & \\
$\mathrm{C}_{3}$ herbaceous & & & 0 & 0.01 \\
\hline
\end{tabular}

\section{Appendix B}

\section{Emission capacities}

Emission capacities for isoprene and monoterpenes were assigned based on an inventory of measurements that have taken place primarily within the model domain. The measurements as well as the derived emission capacities are given in Table B1. 
Table B1. Emission capacities for isoprene $\left(I_{S}\right)$ and monoterpenes $\left(M_{S}\right)$ applied in the simulation (printed in bold), and the studies these averages are based on. For studies in which multiple values are reported (e.g. for different months, different plants, or different algorithms) the range of values in the publication is given as an indicator of the variability. Measurements were done using branch enclosures, unless otherwise stated, and standardization was done using a temperature and light dependency for isoprene and a temperature dependency for monoterpenes, unless otherwise stated.

\begin{tabular}{|c|c|c|c|}
\hline species and location & $\begin{array}{l}I_{S} \\
\left(\mu \mathrm{g} \mathrm{g}^{-1} \mathrm{DW} \mathrm{h}^{-1}\right)\end{array}$ & $\begin{array}{l}M_{S} \\
\left(\mu \mathrm{g} \mathrm{g}^{-1} \mathrm{DW} \mathrm{h}^{-1}\right)\end{array}$ & source \\
\hline Abies alba & 0.05 & 0.9 & \\
\hline France, Vosges & $<0.1$ & 0.89 & 24 \\
\hline Betula pendula & 0.2 & 3.0 & \\
\hline Austria, Lobau & & 0.19 & $20^{++}$ \\
\hline Finland, Finnish Forest Research Institute & $0.18(0 .-1.5)$ & $5.7(0 .-11.5)$ & $6^{+}$ \\
\hline Finland, Finnish Forest Research Institute & & $0.7-7.7$ & 7 \\
\hline UK & 0. & 0 & $11^{* * * *}$ \\
\hline Betula pubescens & $\mathbf{0 .}$ & 0.5 & \\
\hline Finland, Finnish Forest Research Institute & & $0.3-5.5$ & 7 \\
\hline UK & 0. & 0. & $11^{* * * *}$ \\
\hline Carpinus betulus & $\mathbf{0 .}$ & 0.04 & \\
\hline Austria, Lobau & 0. & 0.04 & 20 \\
\hline Corylus avellana & $\mathbf{0 .}$ & $\mathbf{0 .}$ & \\
\hline UK & 0. & 0. & $11^{* * * *}$ \\
\hline Fagus sylvatica & $\mathbf{0 .}$ & $10.0^{*}$ & \\
\hline Austria, Jägerwiese & & $0.24-0.47$ & $20^{++}$ \\
\hline France, Vosges & 0 . & $43.5(42.4-44.2)^{*}$ & 23 \\
\hline Germany, Jülich & & $2.9-12.9^{*}$ & 4 \\
\hline Germany, Jülich & & $0.7-20.8^{*}$ & 12 \\
\hline Switzerland, Dübendorf & 0. & & $35^{++}$ \\
\hline UK & 0. & 0. & $11^{* * * *}$ \\
\hline Fraxinus excelsior & 0. & 0. & \\
\hline UK & 0. & 0. & $11^{* * * *}$ \\
\hline Juniperus oxycedrus & 0. & 1.0 & \\
\hline France, Montpellier & 0. & $0.5<M_{S}<20$ & 26 \\
\hline Italy, Castelporziano & 0.09 & 0.96 & 25 \\
\hline Italy, Castelporziano & 0. & $0.5<M_{S}<20$ & 26 \\
\hline Spain, Burriana & 0. & $0.5<M_{S}<20$ & 26 \\
\hline Picea abies & 0.5 & 3.0 & \\
\hline Denmark, Ulfborg & & $0.73(0.12-1.37)$ & $3^{* *}$ \\
\hline Germany, Fichtelgebirge & $0.32 / 1.7$ & 0.50 & 5 \\
\hline Sweden, Asa & 0.38 & 0.27 & $17^{* * *}$ \\
\hline Sweden, Gällivare & & 3.8 & $15^{* * *}$ \\
\hline Sweden, NOPEX site & $1.63 \pm 1.22$ & $2.31-8.30$ & 16 \\
\hline Sweden, Simlångsdalen & & 0.3 & $15^{* * *}$ \\
\hline Sweden, Vindeln & & 0.08 & $15^{* * *}$ \\
\hline UK & 0. & & $11^{\text {**** }}$ \\
\hline Pinus halepensis & 0. & 5.0 & \\
\hline France, La Barben & & 14.76 & 32 \\
\hline Spain, Burriana & 0 . & $0.5<M_{S}<20$ & 26 \\
\hline Spain, Collserola & & $3-11.0$ & 22 \\
\hline Spain, Collserola & & $2-23$ & 28 \\
\hline greenhouse & 0. & 0.41 & 27 \\
\hline
\end{tabular}


Table B1. Continued.

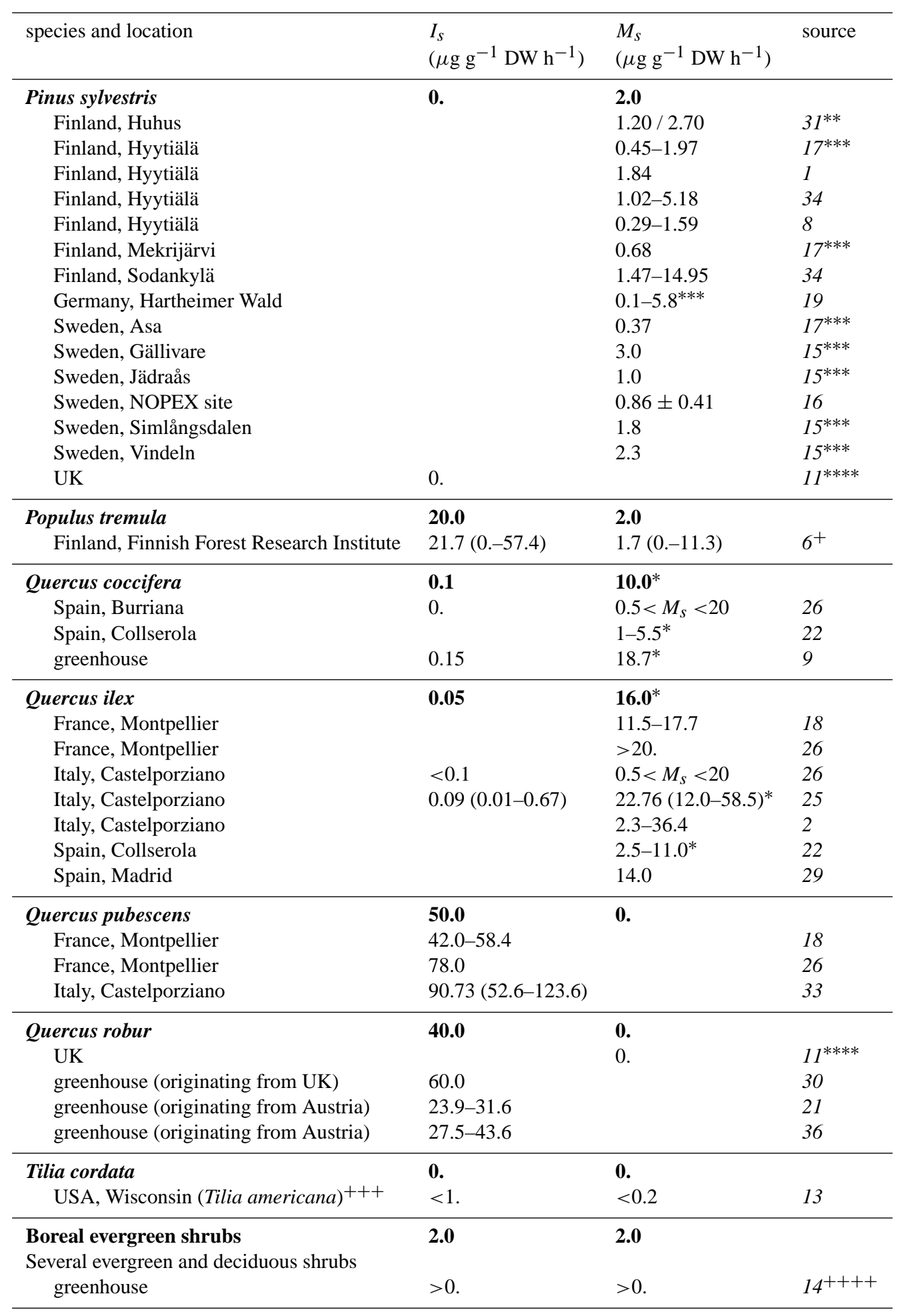


Table B1. Continued.

\begin{tabular}{|c|c|c|c|}
\hline species and location & $\begin{array}{l}I_{S} \\
\left(\mu \mathrm{g} \mathrm{g}^{-1} \mathrm{DW} \mathrm{h}^{-1}\right)\end{array}$ & $\begin{array}{l}M_{S} \\
\left(\mu \mathrm{g} \mathrm{g}^{-1} \mathrm{DW} \mathrm{h}^{-1}\right)\end{array}$ & source \\
\hline Mediterranean raingreen low shrubs & 2.0 & 2.0 & \\
\hline \multicolumn{4}{|l|}{ Cistus albidus } \\
\hline Spain, Collserola & & $2-32.8$ & 22 \\
\hline \multicolumn{4}{|l|}{ Cistus incanus } \\
\hline greenhouse & 0. & 3.55 & 27 \\
\hline \multicolumn{4}{|l|}{ Cistus monspeliensis } \\
\hline greenhouse & 0. & 17.05 & 27 \\
\hline \multicolumn{4}{|l|}{ Cistus salvifolius } \\
\hline greenhouse & 0. & 3.50 & 27 \\
\hline \multicolumn{4}{|l|}{ Erica arborea } \\
\hline Italy, Castelporziano & $20.34 \pm 7.05$ & & 25 \\
\hline Italy, Castelporziano & 6.36 & & 10 \\
\hline Spain, Collserola & & $3-17.5^{*}$ & 22 \\
\hline \multicolumn{4}{|l|}{ Lavandula stoechas } \\
\hline Spain, Burriana & 0. & $0.5<M_{S}<20$ & 26 \\
\hline greenhouse & 0. & 18.16 & 27 \\
\hline \multicolumn{4}{|l|}{ Myrtus communis } \\
\hline Italy, Castelporziano & $136.7 \pm 104$ & $0.29 \pm 0.28$ & 25 \\
\hline \multicolumn{4}{|l|}{ Rosmarinus officinalis } \\
\hline Italy, Castelporziano & & $2.19 \pm 0.29$ & 10 \\
\hline greenhouse & 0. & 6.58 & 27 \\
\hline \multicolumn{4}{|l|}{ Thymus vulgaris } \\
\hline France, Montpellier & 0. & $0.1<M_{S}<0.5$ & 26 \\
\hline greenhouse & 0. & 4.98 & 27 \\
\hline $\mathrm{C}_{3}$ herbaceous / pastures & $\mathbf{0 .}$ & 0.5 & \\
\hline Austria, Silberwald & & 0.02 & $20^{++}$ \\
\hline Austria, Strasshof & & $0.01-0.20$ & $20^{++}$ \\
\hline Crops & $\mathbf{0 .}$ & 0.10 & \\
\hline \multicolumn{4}{|l|}{ Rapeseed (Brassica napus) } \\
\hline Austria, Essling & 0. & $0.07-0.20$ & 20 \\
\hline \multicolumn{4}{|l|}{ Rye (Secale cereale) } \\
\hline Austria, Essling & 0. & $0.05-0.15$ & 20 \\
\hline \multicolumn{4}{|l|}{ Wheat (Triticum aestivum) } \\
\hline Austria, Laxenburg & 0. & 0. & 20 \\
\hline
\end{tabular}

1 Bäck et al. (2005); 2 Bertin et al. (1997); 3 Christensen et al. (2000); 4 Dindorf et al. (2006); 5 Grabmer et al. (2006); 6 Hakola et al. (1998); 7 Hakola et al. (2001); 8 Hakola et al. (2006); 9 Hansen and Seufert (1996); 10 Hansen et al. (1997); 11 Hewitt and Street (1992); 12 Holzke et al. (2006); 13 Isebrands et al. (1999); 14 Isidorov et al. (1985); 15 Janson (1993); 16 Janson et al. (1999); 17 Janson and de Serves (2001); 18 Kesselmeier et al. (1998); 19 Komenda and Koppmann (2002); 20 König et al. (1995); 21 Lehning et al. (1999); 22 Llusia and Penuelas (2000); 23 Moukhtar et al. (2005); 24 Moukhtar et al. (2006); 25 Owen et al. (1997); 26 Owen et al. (1998); 27 Owen et al. (2002); 28 Peñuelas and Llusià (1999); 29 Plaza et al. (2005); 30 Possell et al. (2004); 31 Rinne et al. (2000); 32 Simon et al. (2005); 33 Steinbrecher et al. (1997); 34 Tarvainen et al. (2005); 35 Tollsten and Muller (1996); 36 Zimmer et al. (2000) * monoterpene emissions calculated with temperature and light dependence; ${ }^{* *}$ derived from fluxes measured at canopy scale; ${ }^{* * *}$ recalculated to standard temperature of $30^{\circ} \mathrm{C}$ from $20^{\circ} \mathrm{C}$ or $25^{\circ} \mathrm{C}$ standardized value; ${ }^{* * * *}$ leaves were harvested before enclosure; ${ }^{+}$average and range as calculated from non-standardized data; ${ }^{++}$VOCs detected, but radiation and/or temperature data are missing for standardization; +++ Observations for Tilia cordata were not found in the literature, so applying values for Tilia americana from USA; ${ }^{++++}$Quantitative observations from European boreal shrubs were not found. 
Acknowledgements. This research was supported by grants from Vetenskapsrådet, FORMAS and the European Commission via a Marie Curie Excellence grant. PM received financial support from project DECVEG from the European Science Foundation under the EUROCORES Programme EuroCLIMATE, through contract no. ERAS-CT-2003-980409 of the European Commission, DG Research, FP6, as well as from the EU-FP6 project ALARM. TH was partly funded by the EU-FP6 Integrated Project ECOCHANGE (Challenges in assessing and forecasting biodiversity and ecosystem changes in Europe, No: 066866 GOCE).

Edited by: G. Wohlfahrt

\section{References}

Arneth, A., Miller, P., Scholze, M., Hickler, T., Schurgers, G., Smith, B., and Prentice, I.: $\mathrm{CO}_{2}$ inhibition of global terrestrial isoprene emissions: Potential implications for atmospheric chemistry, Geophys. Res. Lett., 34, L18813, doi:10.1029/ 2007GL030615, 2007a.

Arneth, A., Niinemets, Ü., Pressley, S., Bäck, J., Hari, P., Karl, T., Noe, S., Prentice, I. C., Serça, D., Hickler, T., Wolf, A., and Smith, B.: Process-based estimates of terrestrial ecosystem isoprene emissions: incorporating the effects of a direct $\mathrm{CO}_{2}$ isoprene interaction, Atmos. Chem. Phys., 7, 31-53, $2007 \mathrm{~b}$.

Arneth, A., Monson, R. K., Schurgers, G., Niinemets, Ü., and Palmer, P. I.: Why are estimates of global terrestrial isoprene emissions so similar (and why is this not so for monoterpenes)?, Atmos. Chem. Phys., 8, 4605-4620, 2008a.

Arneth, A., Schurgers, G., Hickler, T., and Miller, P.: Effects of species composition, land surface cover, $\mathrm{CO}_{2}$ concentration and climate on isoprene emissions from European forests, Plant Biology, 10, 150-162, doi:10.1055/s-2007-965247, 2008b.

Bäck, J., Hari, P., Hakola, H., Juurola, E., and Kulmala, M.: Dynamics of monoterpene emissions in Pinus sylvestris during early spring, Boreal Environ. Res., 10, 409-424, 2005.

Baraldi, R., Rapparini, F., Oechel, W., Hastings, S., Bryant, P., Cheng, Y., and Miglietta, F.: Monoterpene emission responses to elevated $\mathrm{CO}_{2}$ in a Mediterranean-type ecosystem, New Phytol., 161, 1-21, 2004.

Berger, A.: Long-term variations of daily insolation and Quaternary climate changes, J. Atmos. Sci., 35, 2362-2367, 1978.

Bertin, N., Staudt, M., Hansen, U., Seufert, G., Ciccioli, P., Foster, P., Fugit, J. L., and Torres, L.: Diurnal and seasonal course of monoterpene emissions from Quercus ilex (L.) under natural conditions application of light and temperature algorithms, Atmos. Environ., 31, 135-144, doi:10.1016/S1352-2310(97) 00080-0, 1997.

Bohn, U. and Neuhäusl, R.: Map of the natural vegetation of Europe: Explanatory text with CD ROM, Tech. rep., German Federal Agency for Nature Conservation, 2003.

Christensen, C. S., Hummelshoj, P., Jensen, N. O., Larsen, B., Lohse, C., Pilegaard, K., and Skov, H.: Determination of the terpene flux from orange species and Norway spruce by relaxed eddy accumulation, Atmos. Environ., 34, 3057-3067, 2000.

Claeys, M., Graham, B., Vas, G., Wang, W., Vermeylen, R., Pashynska, V., Cafmeyer, J., Guyon, P., Andreae, M., Artaxo, P., and Maenhaut, W.: Formation of secondary organic aerosols through photooxidation of isoprene, Science, 303, 1173-1176, doi:10.1126/science.1092805, 2004.

Claussen, M.: Late Quaternary vegetation-climate feedbacks, Clim. Past, 5, 203-216, 2009, http://www.clim-past.net/5/203/2009/.

Constable, J., Litvak, M., Greenberg, J., and Monson, R.: Monoterpene emission from coniferous trees in response to elevated $\mathrm{CO}_{2}$ concentration and climate warming, Glob. Change Biol., 5, 255267, 1999.

Dindorf, T., Kuhn, U., Ganzeveld, L., Schebeske, G., Ciccioli, P., Holzke, C., Köble, R., Seufert, G., and Kesselmeier, J.: Significant light and temperature dependent monoterpene emissions from European beech (Fagus sylvatica L.) and their potential impact on the European volitile organic compound budget, J. Geophys. Res., 111, D16305, doi:10.1029/2005JD006751, 2006.

Etheridge, D. M., Steele, L. P., Langenfelds, R. L., Francey, R. J., Barnola, J. M., and Morgan, V. I.: Natural and anthropogenic changes in atmospheric $\mathrm{CO}_{2}$ over the last 1000 years from air in Antarctic ice and firn, J. Geophys. Res.-Atmos., 101, 4115-4128, 1996.

Fletcher, W. and Sánchez-Goñi, M.: Orbital- and sub-orbital-scale climate impact on vegetation of the western Mediterranean basin over the last $48000 \mathrm{yr}$, Quaternary Res., 70, 451-464, doi:10. 1016/j.yqres.2008.07.002, 2008.

Friedli, H., Lötscher, H., Oeschger, H., Siegenthaler, U., and Stauffer, B.: Ice core record of the ${ }^{13} \mathrm{C} /{ }^{12} \mathrm{C}$ ratio of atmospheric $\mathrm{CO}_{2}$ in the past two centuries, Nature, 324, 237-238, 1986.

Fuhrer, K. and Legrand, M.: Continental biogenic species in the Greenland Ice Core Project ice core: Tracing back the biomass history of the North American continent, J. Geophys. Res., 102, 26735-26745, 1997.

Gerten, D., Schaphoff, S., Haberlandt, U., Lucht, W., and Sitch, S.: Terrestrial vegetation and water balance - hydrological evaluation of a dynamic global vegetation model, J. Hydrol., 286, 249-270, 2004.

Giesecke, T. and Bennett, K.: The Holocene spread of Picea abies (L.) Karst. in Fennoscandia and adjacent areas, J. Biogeogr., 31, 1523-1548, 2004.

Giesecke, T., Hickler, T., Kunkel, T., Sykes, M., and Bradshaw, R. H. W.: Towards the understanding of the Holocene distribution of Fagus sylvatica L., J. Biogeogr., 34, 118-131, 2007.

Grabmer, W., Kreuzwieser, J., Wisthaler, A., Cojocariu, C., Graus, M., Rennenberg, M., Steigner, D., Steinbrecher, R., and Hansel, A.: VOC emissions from Norway spruce (Picea abies L. [Karst]) twigs in the field - Results of a dynamic enclosure study, Atmos. Environ., 40, S128-S137, 2006.

Guenther, A., Hewitt, C., Erickson, D., Fall, R., Geron, C., Graedel, T., Harley, P., Klinger, L., Lerdau, M., McKay, W., Pierce, T., Scholes, B., Steinbrecher, R., Tallamraju, R., Taylor, J., and Zimmerman, P.: A global model of natural volatile organic compound emissions, J. Geophys. Res., 100, 8873-8892, 1995.

Hakola, H., Rinne, J., and Laurila, T.: The hydrocarbon emission rates of Tea-leafed willow (Salix phylicifolia), Silver birch (Betula pendula) and European aspen (Populus tremula), Atmos. Environ., 32, 1825-1833, 1998.

Hakola, H., Laurila, T., Lindfors, V., Hellen, H., Gaman, A., and Rinne, J.: Variation of the VOC emission rates of birch species during the growing season, Boreal Environ. Res., 6, 237-249, 2001. 
Hakola, H., Tarvainen, V., Bäck, J., Ranta, H., Bonn, B., Rinne, J., and Kulmala, M.: Seasonal variation of mono- and sesquiterpene emission rates of Scots pine, Biogeosciences, 3, 93-101, 2006, http://www.biogeosciences.net/3/93/2006/.

Hansen, U. and Seufert, G.: The terpenoid emission pattern of Quercus coccifera $\mathrm{L}$. coincides with the emission pattern found with Quercus ilex L., in: Proceedings of EUROTRAC Symposium '96: Transport and transformation of poluttants in the troposphere, edited by: Borrell, P., Borrell, P., Kelly, K., Cvitaš, T., and Seiler, W., vol. 2: Emissions, deposition, laboratory work and instrumentation, 1996.

Hansen, U., Van Eijk, J., Bertin, N., Staudt, M., Kotzias, D., Seufert, G., Fugit, J. L., Torres, L., Cecinato, A., Brancaleoni, E., Ciccioli, P., and Bomboi, T.: Biogenic emissions and $\mathrm{CO}_{2}$ gas exchange investigated on four Mediterranean shrubs, Atmos. Environ., 31, 157-166, 1997.

Heald, C., Wilkinson, M. J., Monson, R., Alo, C., Wang, G., and Guenther, A.: Response of isoprene emission to ambient $\mathrm{CO}_{2}$ changes and implications for global budgets, Glob. Change Biol., 15, 1127-1140, doi:10.1111/j.1365-2486.2008.01803.x, 2009.

Hewitt, C., Stewart, H., Street, R., and Scholefield, P.: Isoprene and monoterpene-emitting species survey 1997, online available at: http://www.es.lancs.ac.uk/cnhgroup/download.html, 1997.

Hewitt, C. N. and Street, R. A.: A qualitative assessment of the emission of nonmethane hydrocarbon compounds from the biosphere to the atmosphere in the Uk - Present knowledge and uncertainties, Atmos. Environ. A, 26, 3069-3077, 1992.

Hickler, T., Smith, B., Sykes, M., Davis, M., Sugita, S., and Walker, K.: Using a generalized vegetation model to simulate vegetation dynamics in Northeastern USA, Ecology, 85, 519-530, 2004.

Hickler, T., Fronzek, S., Araújo, M., Schweiger, O., Thuiller, W., and Sykes, M.: An ecosystem model-based estimate of changes in water availability differs from water proxies that are commonly used in species distribution models, Global Ecol.Biogeogr., 18, 304-313, doi:10.1111/j.1466-8238.2009. 00455.x, 2009a.

Hickler, T., Vohland, K., Miller, P., Smith, B., Costa, L., Feehan, J., Giesecke, T., Fronzek, S., Carter, T., Cramer, W., Kühn, I., and Sykes, M.: Climate-driven changes in European potential natural vegetation in relation to the Natura 2000 protected area network, Global Ecol. Biogeogr., submitted, 2009b.

Hoffmann, T., Odum, J. R., Bowman, F., Collins, D., Klockow, D., Flagan, R. C., and Seinfeld, J. H.: Formation of organic aerosols from the oxidation of biogenic hydrocarbons, J. Atmos. Chem., 26, 189-222, 1997.

Holzke, C., Dindorf, T., Kesselmeier, J., Kuhn, U., and Koppmann, R.: Terpene emissions from European beech (Fagus sylvatica L.): Pattern and emission behaviour over two vegetation periods, J. Atmos. Chem., 55, 81-102, 2006.

Huntley, B.: Vegetation history, chap. Europe, Kluwer Academic Publishers, 341 pp., 1988.

Indermühle, A., Stocker, T., Joos, F., Fischer, H., Smith, H., Wahlen, M., Deck, B., Mastroianni, D., Tschumi, J., Blunier, T., Meyer, R., and Stauffer, B.: Holocene carbon-cycle dynamics based on $\mathrm{CO}_{2}$ trapped in ice at Taylor Dome, Antarctica, Nature, 398, 121-126, 1999.

Isebrands, J., Guenther, A., Harley, P., Helmig, D., Klinger, L., Vierling, L., Zimmerman, P., and Geron, C.: Volatile organic compound emission rates from mixed deciduous and coniferous forests in Northern Wisconsin, USA, Atmos. Environ., 33, 25272536, 1999.

Isidorov, V., Zenkevich, I., and Ioffe, B.: Volatile organic compounds in the atmosphere of forests, Atmos. Environ., 19, 1-8, 1985.

Janson, R.: Monoterpene emissions from Scots pine and Norwegian spruce, J. Geophys. Res.-Atmos., 98, 2839-2850, 1993.

Janson, R. and de Serves, C.: Acetone and monoterpene emissions from the boreal forest in northern Europe, Atmos. Environ., 35, 4629-4637, 2001.

Janson, R., De Serves, C., and Romero, R.: Emission of isoprene and carbonyl compounds from a boreal forest and wetland in Sweden, Agr. Forest Meteorol., 98-9, 671-681, 1999.

Kaplan, J., Folberth, G., and Hauglustaine, D.: Role of methane and biogenic volatile organic compound sources in late glacial and Holocene fluctuations of atmospheric methane concentrations, Global Biogeochem. Cy., 20, GB2016, doi:10.1029/ 2005GB002590, 2006.

Karl, M., Guenther, A., Köble, R., Leip, A., and Seufert, G.: A new European plant-specific emission inventory of biogenic volatile organic compounds for use in atmospheric transport models, Biogeosciences, 6, 1059-1087, 2009, http://www.biogeosciences.net/6/1059/2009/.

Keeling, C. D., Whorf, T. P., Wahlen, M., and Vanderplicht, J.: Interannual Extremes In The Rate Of Rise Of Atmospheric CarbonDioxide Since 1980, Nature, 375, 666-670, 1995.

Kellomaki, S., Rouvinen, I., Peltola, H., Strandman, H., and Steinbrecher, R.: Impact of global warming on the tree species composition of boreal forests in Finland and effects on emissions of isoprenoids, Glob. Change Biol., 7, 531-544, 2001.

Kesselmeier, J. and Staudt, M.: Biogenic volatile organic compounds (VOC): An overview on emission, physiology and ecology, J. Atmos. Chem., 33, 23-88, 1999.

Kesselmeier, J., Bode, K., Schafer, L., Schebeske, G., Wolf, A., Brancaleoni, E., Cecinato, A., Ciccioli, P., Frattoni, M., Dutaur, L., Fugit, J. L., Simon, V., and Torres, L.: Simultaneous field measurements of terpene and isoprene emissions from two dominant mediterranean oak species in relation to a North American species, Atmos. Environ., 32, 1947-1953, doi: 10.1016/S1352-2310(97)00500-1, 1998.

Koca, D., Smith, B., and Sykes, M.: Modelling regional climate change effects on potential natural ecosystems in Sweden, Climatic Change, 78, 381-406, 2006.

Komenda, M. and Koppmann, R.: Monoterpene emissions from Scots pine (Pinus sylvestris): Field studies of emission rate variabilities, J. Geophys. Res.-Atmos., 107, 4161, doi:10.1029/2001JD000691, 2002.

König, G., Brunda, M., Puxbaum, H., Hewitt, C., Duckham, S., and Rudolph, J.: Relative contribution of oxygenated hydrocarbons to the total biogenic VOC emissions of selected mid-European agricultural and natural plant species, Atmos. Environ., 29, 861874, 1995.

Kroll, J. H., Ng, N. L., Murphy, S. M., Flagan, R. C., and Seinfeld, J. H.: Secondary organic aerosol formation from isoprene photooxidation under high- $\mathrm{NO}_{\mathrm{x}}$ conditions, Geophys. Res. Lett., 32, L18808, doi:10.1029/2005GL023637, 2005.

Lang, G.: Quartäre Vegetationsgeschichte Europas, Gustav Fischer Verlag, 1994.

Lathiére, J., Hauglustaine, D. A., Friend, A. D., De Noblet- 
Ducoudré, N., Viovy, N., and Folberth, G. A.: Impact of climate variability and land use changes on global biogenic volatile organic compound emissions, Atmos. Chem. Phys., 6, 2129-2146, 2006 ,

http://www.atmos-chem-phys.net/6/2129/2006/.

Legrand, M. and De Angelis, M.: Origins and variations of light carboxylic acids in polar precipitation, J. Geophys. Res., 100, 1445-1462, 1995.

Legrand, M., Preunkert, S., Wagenbach, D., Cachier, H., and Puxbaum, H.: A historical record of formate and acetate from a high-elevation Alpine glacier: Implications for their natural versus anthropogenic budgets at the European scale, J. Geophys. Res., 108, 4788, doi:10.1029/2003JD003594, 2003.

Lehning, A., Zimmer, I., Steinbrecher, R., Bruggemann, N., and Schnitzler, J. P.: Isoprene synthase activity and its relation to isoprene emission in Quercus robur L-leaves, Plant Cell Environ., 22, 495-504, 1999.

Levis, S., Wiedinmyer, C., Bonan, G., and Guenther, A.: Simulating biogenic volatile organic compound emissions in the Community Climate System Model, J. Geophys. Res., 108, 4659, doi: 10.1029/2002JD003203, 2003.

Llorens, L., Llusià, J., Murchie, E., Peñuelas, J., and Beerling, D. J.: Monoterpene emissions and photoinhibition of "living fossil" trees grown under $\mathrm{CO}_{2}$ enrichment in a simulated Cretaceous polar environment, J. Geophys. Res., 114, G01005, doi: 10.1029/2008JG000802, 2009.

Llusia, J. and Penuelas, J.: Seasonal patterns of terpene content and emission from seven Mediterranean woody species in field conditions, Am. J. Bot., 87, 133-140, 2000.

Loreto, F., Mannozzi, M., Maris, C., Nascetti, P., Ferranti, F., and Pasqualini, S.: Ozone quenching properties of isoprene and its antioxidant role in leaves, Plant Physiol., 126, 993-1000, 2001.

Mikolajewicz, U., Groger, M., Maier-Reimer, E., Schurgers, G., Vizcaino, M., and Winguth, A. M. E.: Long-term effects of anthropogenic $\mathrm{CO} 2$ emissions simulated with a complex earth system model, Clim. Dynam., 28, 599-631, 2007.

Miller, P. A., Giesecke, T., Hickler, T., Bradshaw, R. H. W., Smith, B., Seppä, H., Valdes, P. J., and Sykes, M. T.: Exploring climatic and biotic controls on Holocene vegetation change in Fennoscandia, J. Ecol., 96, 247-259, doi:10.1111/j.1365-2745.2007.01342. $\mathrm{x}, 2008$.

Mitchell, T. D. and Jones, P. D.: An improved method of constructing a database of monthly climate observations and associated high-resolution grids, Int. J. Climatol., 25, 693-712, 2005.

Morales, P., Sykes, M. T., Prentice, I. C., Smith, P., Smith, B., Bugmann, H., Zierl, B., Friedlingstein, P., Viovy, N., Sabaté, S., Sánchez, A., Pla, E., Gracia, C. A., Sitch, S., Arneth, A., and Ogee, J.: Comparing and evaluating process-based ecosystem model predictions of carbon and water fluxes in major European forest biomes, Glob. Change Biol., 11, 2211-2233, doi: 10.1111/j.1365-2486.2005.01036.x, 2005.

Moukhtar, S., Bessagnet, B., Rouil, L., and Simon, V.: Monoterpene emissions from Beech (Fagus sylvatica) in a French forest and impact on secondary pollutants formation at regional scale, Atmos. Environ., 39, 3535-3547, 2005.

Moukhtar, S., Couret, C., Rouil, L., and Simon, V.: Biogenic Volatile Organic Compounds (BVOCs) emissions from Abies alba in a French forest, Sci. Total Environ., 354, 232-245, 2006.

Naik, V., Delire, C., and Wuebbles, D.: Sensitivity of global biogenic isoprenoid emissions to climate variability and atmospheric $\mathrm{CO}_{2}$, J. Geophys. Res., 109, D06301, doi:10.1029/ 2002JD003203, 2004.

New, M., Hulme, M., and Jones, P.: Representing twentieth-century space-time climate variability. Part II: Development of 1901-96 monthly grids of terrestrial surface climate, J. Climate, 13, 22172238, 2000.

Niinemets, Ü., Tenhunen, J., Harley, P., and Steinbrecher, R.: A model of isoprene emission based on energetic requirements for isoprene synthesis and leaf photosynthetic properties for Liquidambar and Quercus, Plant Cell Environ., 22, 1319-1335, 1999.

Niinemets, Ü., Seufert, G., Steinbrecher, R., and Tenhunen, J.: A model coupling foliar monoterpene emissions to leaf photosynthetic characteristics in Mediterranean evergreen Quercus species, New Phytol., 153, 257-275, 2002.

Owen, S., Boissard, C., Street, R., Duckham, S., Csiky, O., and Hewitt, C.: Screening of 18 mediterranean plant species for volatile organic compound emissions, Atmos. Environ., 31, 101-117, 1997.

Owen, S., Boissard, C., Hagenlocher, B., and Hewitt, C.: Field studies of isoprene emissions from vegetation in the Northwest Mediterranean region, J. Geophys. Res., 103, 25499-25511, 1998.

Owen, S., Harley, P., Guenther, A., and Hewitt, C.: Light dependency of VOC emissions from selected Mediterranean plants, Atmos. Environ., 36, 3147-3159, 2002.

Peñuelas, J. and Llusià, J.: Short-term response of terpene emission rates to experimental changes of PFD in Pinus halepensis and Quercus ilex in summer field conditions, Environ. Exp. Botany, 42, 61-68, 1999.

Peltier, W.: Ice age paleotopography, Science, 265, 195-201, 1994.

Plaza, J., Nunez, L., Pujadas, M., Perrez-Pastor, R., Bermejo, V., Garcia-Alonso, S., and Elvira, S.: Field monoterpene emission of Mediterranean oak (Quercus ilex) in the central Iberian Peninsula measured by enclosure and micrometeorological techniques: Observation of drought stress effect, J. Geophys. Res.-Atmos., 110, D03303, doi:10.1029/2004JD005168, 2005.

Pope, V. D., Gallani, M. L., Rowntree, P. R., and Stratton, R. A.: The impact of new physical parametrizations in the Hadley Centre climate model: HadAM3, Clim. Dynam., 16, 123-146, doi: 10.1007/s003820050009, 2000.

Possell, M., Heath, J., Nicholas Hewitt, C., Ayres, E., and Kerstiens, G.: Interactive effects of elevated $\mathrm{CO}_{2}$ and soil fertility on isoprene emissions from Quercus robur, Glob. Change Biol., 10, 1835-1843, 2004.

Possell, M., Hewitt, C. N., and Beerling, D. J.: The effects of glacial atmospheric $\mathrm{CO}_{2}$ concentrations and climate on isoprene emissions by vascular plants, Glob. Change Biol., 11, 60-69, 2005.

Ramankutty, N., Evan, A. T., Monfreda, C., and Foley, J. A.: Farming the planet: 1. Geographic distribution of global agricultural lands in the year 2000, Global Biogeochem. Cy., 22, GB1003, doi:10.1029/2007GB002952, 2008.

Rinne, J., Hakola, H., Laurila, T., and Rannik, U.: Canopy scale monoterpene emissions of Pinus sylvestris dominated forests, Atmos. Environ., 34, 1099-1107, 2000.

Rosenstiel, T. N., Potosnak, M. J., Griffin, K. L., Fall, R., and Monson, R. K.: Increased $\mathrm{CO}_{2}$ uncouples growth from isoprene emission in an agriforest ecosystem, Nature, 421, 256-259, 2003. 
Ruddiman, W. F.: The challenge of modeling interglacial $\mathrm{CO}_{2}$ and $\mathrm{CH}_{4}$ trends, Quaternary Sci. Rev., 27, 445-448, doi:10.1016/j. quascirev.2007.11.007, 2008.

Savarino, J. and Legrand, M.: High northern latitude forest fires and vegetation emissions over the last millennium inferred from the chemistry of a central Greenland ice core, J. Geophys. Res., 103, 8267-8279, 1998.

Schurgers, G., Mikolajewicz, U., Gröger, M., Maier-Reimer, E., Vizcaíno, M., and Winguth, A.: Dynamics of the terrestrial biosphere, climate and atmospheric $\mathrm{CO}_{2}$ concentration during interglacials: a comparison between Eemian and Holocene, Clim. Past, 2, 205-220, 2006, http://www.clim-past.net/2/205/2006/.

Schurgers, G., Arneth, A., Holzinger, R., and Goldstein, A. H.: Process-based modelling of biogenic monoterpene emissions combining production and release from storage, Atmos. Chem. Phys., 9, 3409-3423, 2009, http://www.atmos-chem-phys.net/9/3409/2009/.

Simon, E., Kuhn, U., Rottenberger, S., Meixner, F., and Kesselmeier, J.: Coupling isoprene and monoterpene emissions from Amazonian tree species with physiological environmental parameters using a neural network approach, Plant Cell Environ., 28, 287-301, 2005.

Simpson, D., Guenther, A., Hewitt, C. N., and Steinbrecher, R.: Biogenic emissions in Europe. 1. Estimates and uncertainties, J. Geophys. Res.-Atmos., 100, 22875-22890, 1995.

Simpson, D., Winiwarter, W., Borjesson, G., Cinderby, S., Ferreiro, A., Guenther, A., Hewitt, C. N., Janson, R., Khalil, M. A. K., Owen, S., Pierce, T. E., Puxbaum, H., Shearer, M., Skiba, U., Steinbrecher, R., Tarrason, L., and Oquist, M. G.: Inventorying emissions from nature in Europe, J. Geophys. Res.-Atmos., 104, 8113-8152, 1999.

Sitch, S., Smith, B., Prentice, I., Arneth, A., Bondeau, A., Cramer, W., Kaplan, J., Levis, S., Lucht, W., Sykes, M., Thonicke, K., and Venevsky, S.: Evaluation of ecosystem dynamics, plant geography and terrestrial carbon cycling in the LPJ Dynamic Global Vegetation Model, Glob. Change Biol., 9, 161-185, 2003.

Sitch, S., Cox, P., Collins, W., and Huntingford, C.: Indirect radiative forcing of climate change through ozone effects on the landcarbon sink, Nature, 448, 791-794, doi:10.1038/nature06059, 2007.

Smiatek, G. and Steinbrecher, R.: Temporal and spatial variation of forest VOC emissions in Germany in the decade 1994-2003, Atmos. Environ., 40, S166-S177, 2006.

Smith, B., Prentice, I., and Sykes, M.: Representation of vegetation dynamics in the modelling of terrestrial ecosystems: comparing two contrasting approaches within European climate space, Glob. Ecol. Biogeogr., 10, 621-637, 2001.
Snow, M., Bard, R., Olszyk, D., Minster, L., Hager, A., and Tingey, D.: Monoterpene levels in needles of Douglas fir exposed to elevated $\mathrm{CO}_{2}$ and temperature, Physiologia Plantarum, 117, 352358, 2003.

Staudt, M., Joffre, R., Rambal, S., and Kesselmeier, J.: Effect of elevated $\mathrm{CO}_{2}$ on monoterpene emission of young Quercus ilex trees and its relation to structural and ecophysiological parameters, Tree Physiol., 21, 437-445, 2001.

Steinbrecher, R., Hauff, K., Rabong, R., and Steinbrecher, J.: Isoprenoid emission of Oak species typical for the Mediterranean area: source strength and controlling variables, Atmos. Environ., 31, 79-88, 1997.

Steinbrecher, R., Smiatek, G., Köble, R., Seufert, G., Theloke, J., Hauff, K., Ciccioli, P., Vautard, R., and Curci, G.: Intra- and inter-annual variability of VOC emissions from natural and seminatural vegetation in Europe and neighbouring countries, Atmos. Environ., 43, 1380-1391, doi:10.1016/j.atmosenv.2008.09.072, 2009.

Tarvainen, V., Hakola, H., Hellén, H., Bäck, J., Hari, P., and Kulmala, M.: Temperature and light dependence of the VOC emissions of Scots pine, Atmos. Chem. Phys., 5, 989-998, 2005, http://www.atmos-chem-phys.net/5/989/2005/.

Tollsten, L. and Muller, P. M.: Volatile organic compounds emitted from beech leaves, Phytochemistry, 43, 759-762, 1996.

Valdes, P., Beerling, D. J., and Johnson, C.: The ice age methane budget, Geophys. Res. Lett., 32, L02704, doi:10.1029/2004GL021004, 2005.

Wiedinmyer, C., Guenther, A., Harley, P., Hewitt, C., Geron, C., Artaxo, P., Steinbrecher, R., and Rasmussen, R.: Global organic emissions from vegetation, Kluwer Academic Publishers, 115-170, online available at: http://bai.acd.ucar.edu/Data/ BVOC/index.shtml, 2004.

Wilkinson, M. J., Monson, R., Trahan, N., Lee, S., Brown, E., Jackson, R., Polley, H., Fay, P., and Fall, R.: Leaf isoprene emission rate as a function of atmospheric $\mathrm{CO}_{2}$ concentration, Glob. Change Biol., 15, 1189-1200, doi:10.1111/j.1365-2486. 2008.01803.x, 2009.

Zimmer, W., Bruggemann, N., Emeis, S., Giersch, C., Lehning, A., Steinbrecher, R., and Schnitzler, J. P.: Process-based modelling of isoprene emission by oak leaves, Plant Cell Environ., 23, 585595, 2000. 